University of Louisville

ThinkIR: The University of Louisville's Institutional Repository

Electronic Theses and Dissertations

1938

\title{
A social and economic history of Louisville, 1860-1865.
}

Edward R. Johnson

University of Louisville

Follow this and additional works at: https://ir.library.louisville.edu/etd

Part of the Cultural History Commons, Public History Commons, Social History Commons, and the United States History Commons

\section{Recommended Citation}

Johnson, Edward R., "A social and economic history of Louisville, 1860-1865." (1938). Electronic Theses and Dissertations. Paper 1808.

https://doi.org/10.18297/etd/1808

This Master's Thesis is brought to you for free and open access by ThinkIR: The University of Louisville's Institutional Repository. It has been accepted for inclusion in Electronic Theses and Dissertations by an authorized administrator of ThinkIR: The University of Louisville's Institutional Repository. This title appears here courtesy of the author, who has retained all other copyrights. For more information, please contact thinkir@louisville.edu. 


\title{
UNIVERSITY OF LOUISVIILE
}

A SOCIAL AID ECONOMIC HISTORY OF LOUISVIILE

$$
1860--1865
$$

\author{
A Disertation \\ Submitted to the Faculty \\ of the Graduate School of the University of Loularille \\ In Partial Fulfiliment of the \\ Requirements for the Degree \\ of Magter of Arts.
}

Department of History

By

Edward R. Johnson, Jr.

Year

1938 
Name

Title A Social and Economic History of Louisvilie,

Director

Approved By:

Director

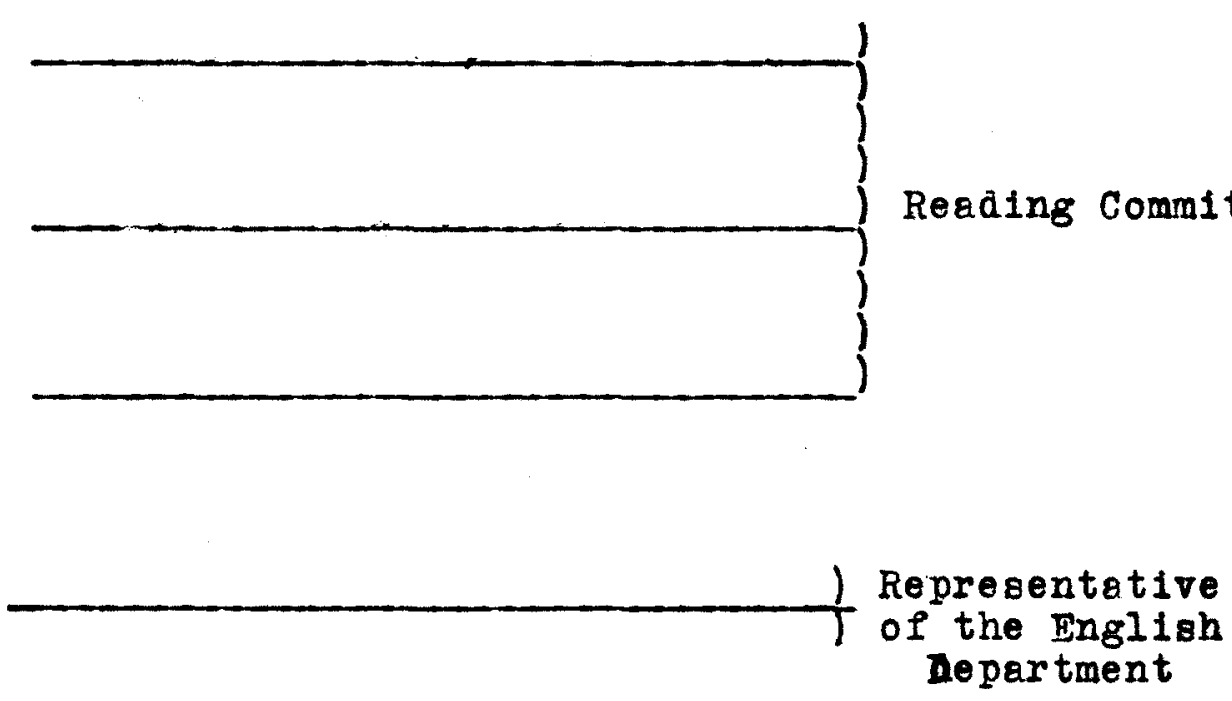

Date- Wlay 24,1938 . 


\section{PREFACE}

The perlod of the Civil wer has alweys stood out with particular interest to both the historian and the layman, but from the point of the part played by an individual city in its oconomic, social and cultural development during the period, little has been done to satisfy the curiosity of either. It has been the purpose of this study to discover the minutiae pertaining to the city of Ioulgrille during the period of the "strife," and, if possible, evaluate and determine thereby what sweeping effeots those "Prag10 Years" had upon the life of the city. No effort, however, has been made to interpret the minutiae in relation to political events, as I believe that the political causations and militery strategy has been adequately treated in numerous volumes and treatises. Then too, their inclusion in this panorama type of study would probably only serve to clutter up the main thread of the narrative. If, in certain instances, the purely historical approach has been abandoned for a more sweeping characterization, it has 
been done to retain the drama, foeling, and atmosphere of the perlod. Let it be understood, however, thet the study is thoroughly documented, that only basic facts have been used in the presentation, and location of important places and events heve been placed as accurately as existing data allowed. Secondary sources have been used only when it was found impossIble to obtain documentary material, and choice has been made as carefully as possible in selecting these materials embodied in the work.

I have cause to thank Dr. W.C. Rallallieu, Professor of History at the University of Louisvilie, who served to develop my interest in the subject, and under whose direction this thesis was written. For numerous courtesies during the research I wish to thank the librery staffs of the University of Louisville, the Cincinnati Public Iibrery; the Louisville Public Library, and the Filson Club. 


\section{TABIE OF CONTENTS}




\section{TABLE OF CONTENTS}

Introduction

Civio Louigrille . . . . . . 10

City government. Population. Police Department. Fire Department. Streets. Public health. Floods. Street oars. Weter problem. The public schools.

Prade and Economic Development - • - 32

Trade with the South. Contraband trade. River trade and traffic. Manufacturing. Employment

Social and Cultural Development . . . 62 Social classes. Churches. Amusements. Dences. Pienics. Gambling and horseracing. Drinking. Dress. Iiterary and Debating societies. Theatre. Masic. Iiterary achievements.

The Aftermath • • • . . 96

CHARTS

Tabulated list of tobacco sales . . . 43

Chart of Menufactures . . . . . 61

Growth of Churches $\quad . \quad$. . 70

MAPS

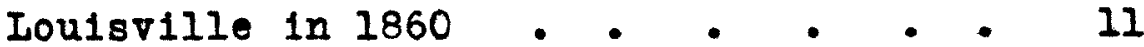

Iouisville in 1865 • . . . . . . 32 
INTRODUCTION 


\section{THE ECONOMIC AND SOCIAI HISTORY OF \\ LOUISVILLE 1860-1865}

\section{INTRODUCTION}

When the fateful question of slavery came irred rocably into the nationgl lime-light, Louisville, "aprawling on the south bank of the Ohio," was a erontier town gone cosmopolitan. The decade from 1850 to 1860 had witnegsed many ohanges in the economic and social life of the city. The provisions of the original charter had been outgrown and replaced by a 1 more comprehensive one in 1851, and the population of the city had increased from 43,194 in $1850^{2}$ to 68,033 in 1860 , or more than forty per cent.

As clty, Louisville had deserted the ranks of "mud flats, false-fronted buildings, and wallowing hogs" to become the commercial center of the state, "a land of comfort and plenty... llourishing city,"

1. Johnston, J. Stoddard, Homorlal History of Loulsvilie, 2 Vol. New York: American Blographical Pubilshing Co., 1896. 1, 91.

2. United States Census, 1850. Population, p. 76.

3. Ibid., 1860. Population, Intro. xviii.

4. Mekay, Chas., Ilfe and Iiberty in America, cited in The History of the Ohio Falls Cities and Their Counties; with Blogrephical sketches, 2 Vol. Cleveland: L.A. Willams, 1881. 1,319. 
5

with sixty miles of pared streets, lit by more than 6 nine-hundred street lamps, and with horse cars running the full length of her Main street. She had become, "next to Cincinnati, which it aspirea to be a rival, the greatest emporium of the pork trade on the North American Continent..." Four raliroads and two 10

wharfs served her enterprising merchents, and her harbor was described as "one of the fineat in the whole course of the Rhine of Amer10a."

Her Main street, which no visitor to the oity falled to describe, was "more than four miles long. perfoctly straight," and wa "bailt up on both sides with good substantial brick bulldings for more then half its length." The stores, taken on the whole, "were the largest and finest warehouses anywhere to be seen, having fronts from twenty to thirty leet wide and three to five stories in height. On the north side of Main street, through-out the whole extent, there were but two retall stores of any kind, and even these only sell goods because they are onabled to do so without interference with their whole-

\footnotetext{
5. Deering, Richard, Loulsville, Her Commerclal, Manufacturing, and Soclal Adventages, Loulsvilie: Hanna \& Co., 1858. p. 3\%.

6. Ib1a., p. 37 .

7. IbId., pp. 37-8.

8. History of the Ohio Falle Cities, 1, 319.

9. Deering, op. c1t., p. 37 .

10. Ib1d., p. 38 .
} 
salo trade." On the south side of the street were "about twenty of the fashionable shops, side by side with many of the largest wholesale houses." The retall stores of the oity were mainly confined to 12

Market and Fourth streets。

The city was well planned. The princlpal streets, from a commerolal point of view, ran east and west, "were from sixty to one-hundred and twenty leet wide, and ran the whole length of the city proper, about four miles without a curve." These were crossed by thirty-five others, equally atraight, and "were from one and half to two miles in length. The aidewalks were from twelve to twenty-five feet wide, and were set with shade trees, exoept in the buginess portion of the city. The average lot was one-hundred and five foot front and two-hundred and ten leet deep and afforded room for gardens, fruit, and ornamental trees." 14

The public buildings were very creditable. The oity Hell, 210 feet long by 122 leet wide, was an "1mposing edffice in the Grecian-Dorio style of arch15

itecture." The United States Custom House, Masonic

11. Webster, op. o1t., p. 133.

12. Johnston, $1,9 \%$

13. Deering, op. c1t., p. 35 .

14. Ibid: EdWard Louigvilie D1rectory, 1864-5. p. 71 .

15. Ibld; Cempbell's Loulsville Business Directory, 1860 . p. 212 . 
Temple, Hospitels, Blind Abylum, Medicel Schools, and "the City Sohool Buildings were the largest and most important of the public buildings. The many churohes were also great additions to the beauty of the oity. Those most worthy of note were the "Walnut Street Baptist, First Presbyterian, Catholic Cathedral, st. Paul's (Episcopal), and the Synagogue; the last mentioned of which is the most elegant building in the city, although it is probably less expenglve than 16

-ither of the others." There were also $81 x$ large 17

white-washed market houses on Market street, "built with iron columns on stone pedestals," where one might buy "fruits and regetables in season."

But there was one institution of which the city was chiefly proud--the Galt House. Of the scores of hotels and boarding houses that welcomed the casual visitor, this hotel alone commanded the attention of the whole world. A feminine visitor in 1858 deseribed it as "over-flowing with hospitality. A real luxury to travelers; good rooms, clean beds, soft cosl fires, and excellent table. It is one of the few cosmopolitan establishments in the Union." ${ }^{19}$ Although a 16. Johnaton, 1,97. 17. Counc1l Reoords, No. 8, p. 371. 18. Deer1ng, op. cit., p. 35. Edward's, op. cit.,p.71. 19. Belle Brittan, On a Tour of Newport, New York: Derby and Jackson, 1858. pp. 6z-73. 
later guest lamented that "the servants of the House wero bondsmen 20 were bondsmen," he too, praised the beds and table. Certeinly the table was something at which to marvel. For the small sum of $50 d$ the Galt House offered christma dinner that rould bewilder a gourmet. The selection of game included such dellcacies as "Sodale of venison with currant jelly; rib of bear with Poirard's sauce; wild turkey with cranberry jelly; red-headed duck stuffed plain; wood duck with hunters seuce; wild goose with pot wine sauce; bridge of buffalo tongue, a la Gedor; aroade of pheasants with green peas, and boar's head. Also a cholce of four soups, two fish, nine hot meats, ten cold ornamented meats, thirty-six entrees; seven relishes, thirteen vegetables, thirty kinds of conlections," and any number of puddings, fruits, and punches.

In most Western cities in the sixties the preferred residential distriot nestled close to the comercial center. Loulaville wa no exception to the rule. The homes of the wealthy business men extended Prom Jefferson to Broadway, north and south,

20. Louisville Ilbrary collection, Collected Writing Relating to the History of Louisville, 2 Vol. Lou1sville, 1935. 1, 215.

21. Massie, J.W., Amer10a, London: John Snow, 1864. pp. $63-4$. 
and from First to Twelfth, east and west. The streets were "Iined on either side with large and elegent shade trees, and the houses are all provided with littlo green yerds in front," surrounded by exquisite wrought iron fences. Here the hoarse whistles of steamboats and factories, and the clatter of the trains, were audible at all hours of the dey and night.

But if the commercial classes were content to IIve olose to the "money market," the less well-to-do had the adrentage of space, quiet, and fresh air of the subarbs. A contemporary writes: "There were no apartment houses or tenements, and slums were unknown; 1t was the ambition of every citizen, no matter what his finanoial status, to own a house to live in." The Iife of Ioulavilio's atreets was a never ending drama replete with oolor and human interest. Before day-light many of the citizens were astir and the sixty miles of macadam and cobble-stone streets, "that jolted your teeth loese," echoed with the rumble of $81 x$ mule team "conestoga" wagons loaded with the farm products of the hinterland. No sooner had the junior clerks appeared to remove the heavy shutters

22. Webster, A.J.s Loulaville in the 1850's" Filson Club H1story Quarterly, Vol. IV. July, 1930.pp. 132. 23. Ib1d., p. 135. 24. IbId.: p. 136 . 
that closed the store fronts to prowlers when the good housewives appeared at "the verious excellent markets" to do their dally shopping for food and household necessities. These selfsame clerks, who often worked as long as sixteen hours a day for throe dollars weok, soon sped away to make deliveries to the awank houses south of Jefferson otreet, virtually taking their lives in their hands as they dodged the young bloods who were taking their morning exercise on spirited horses, hoping to attract attention by their display of horsemenship.

Later in the day oraymen, merchants, and auctioneers vied with the pedestrians for the use of the sidewalks as they unloaded their goods to the warehouses, or, in the latter case, to a suffering public. Loafing on the street corners, and in the coffee houses, was confined to the very old and the young, with a soattered representation of the solid business men who found it conveniently neoessary to have businese on the street at "grog hours." Nor with the coming of darkness did the bustle abate. The mechanics and laborera, followed by their families, paraded the streets for their "after supper exercise," or hurridy plcked their way to their favorite theatre to--as one Archives) 1921. p. 19 . 
writer expressed 1t--"get seats within cat-calling distance of the stage." The unattached males, followed by the heads of many families found the seloons and gambling houses a welcoming attraction after a day of hard labor.

Louloville was more than a lend of plenty, it was the open door of opportunity. Money was plent1ful, and the rapialy growing West, as well as the cotton raising South, was a famished market for produce and manufactured goods. With a small amount of oepital and average business acumen it wes possible to build up a small fortune in a short length of time. Indeed, most of Louigville's great fortunes were built up between 1850 and 1870 .

But "war speaks disorganization and destruction economically and socially; it also speaks ertifical prosperity and new relationships." The city of Loulaville was no exception to this rule. The war period was a time of frenzied money making and unselfish devotion; of high prices and high rents; of unemployment and near starvation; of mass meetings in the City Hall being addressed by "fat stayat-homes and passing grandiloquent resolutions rejoicing in victory or piously dejected in deleat; of repeated calls for thirty-, sixty-, ninety-, 26. Coulter, E. Nerton, whe CIVII War and Readjugt in Kentucky. Chepel Hill: Uni 
and hundred day volunteers." It was a time when anything could happen--and did. The four long years of the Civil War probably witnessed more changes in the economie and social life of the city than did the twenty yoars prior to 1860 . It has been the purpose in the following pages to trace historically this development. 


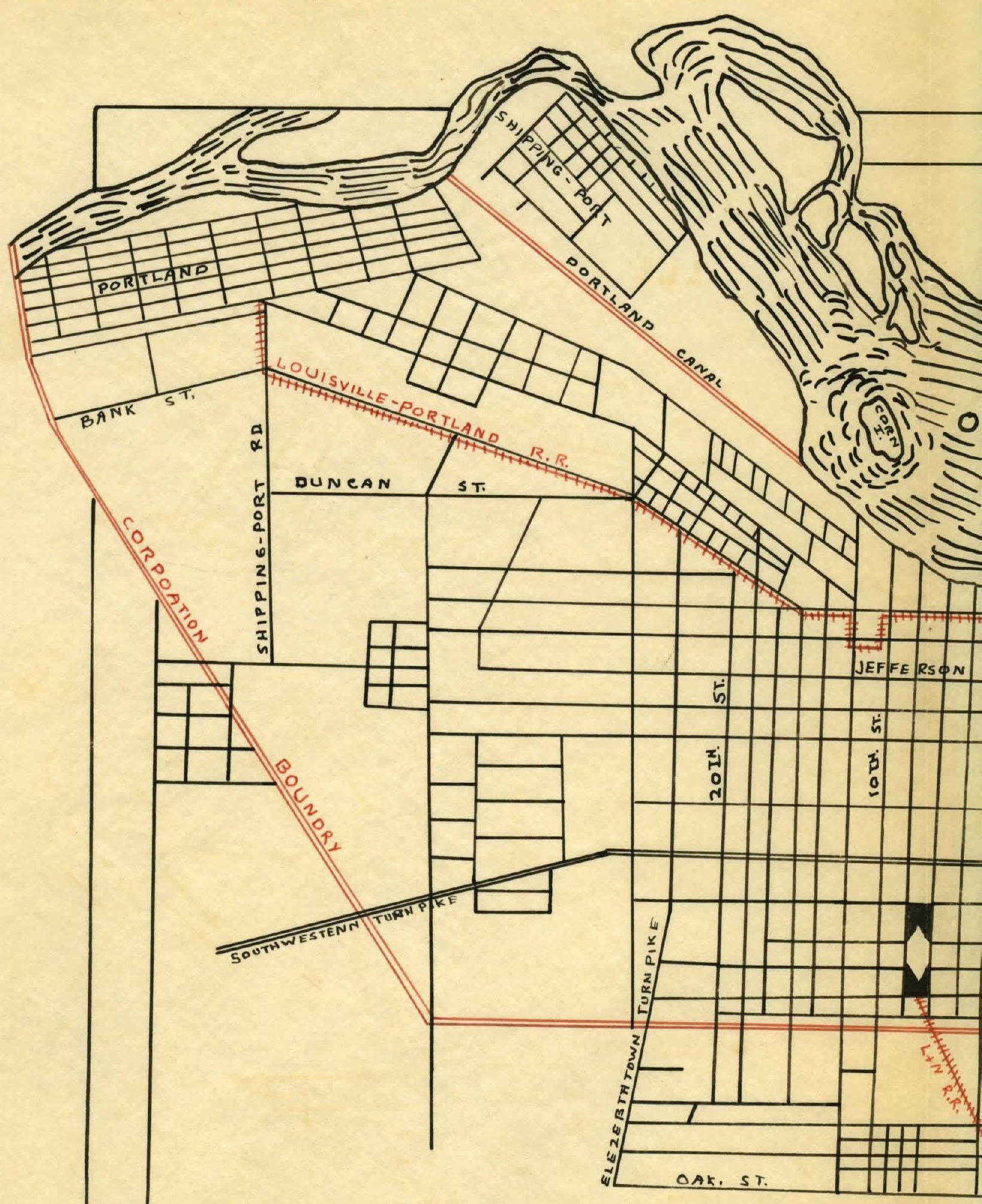

$\prod_{0} 1 \frac{S C A L}{\frac{1}{2} M}$ 


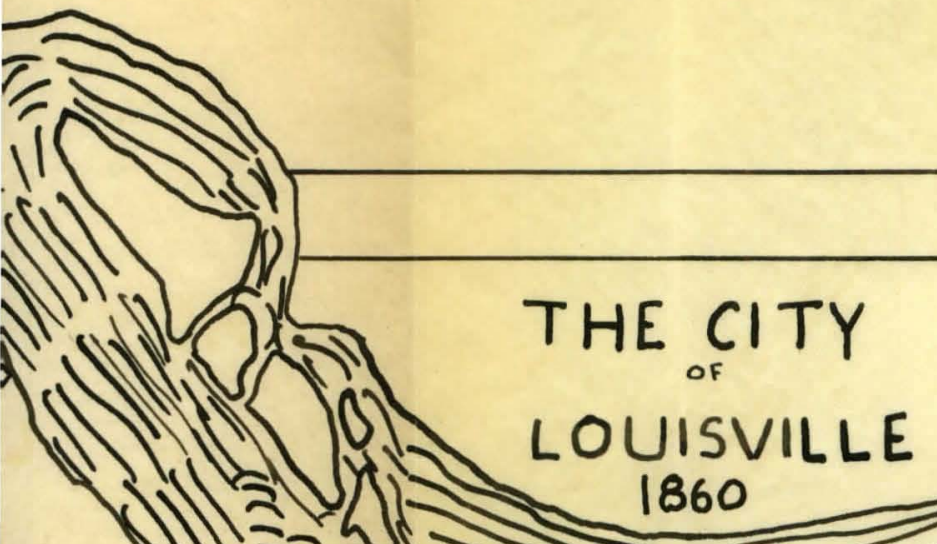

(1)

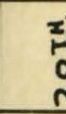

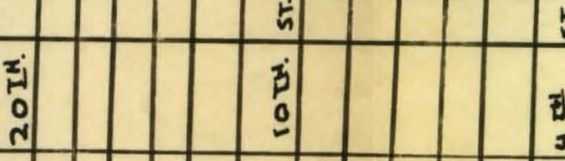

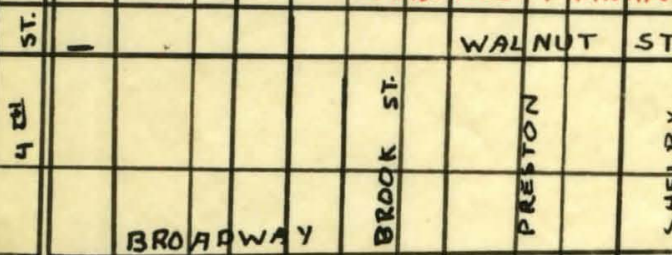

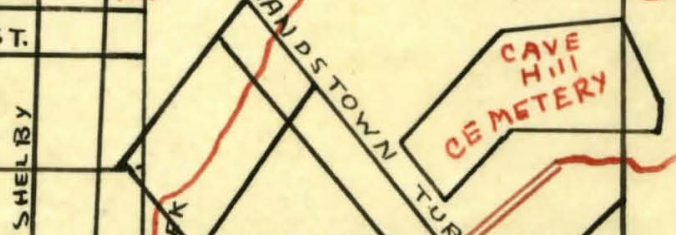

OAK, ST.

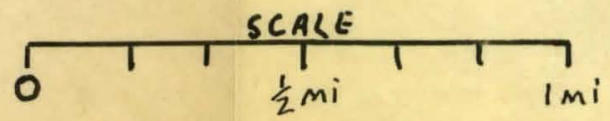




\section{THE ECONOMIC AND SOCIAI HISTORY OF \\ LOUISVILLE $\quad 1860-1865$}

\section{GIVIC LOUISVILIE}

At the beginning of the Civil War Loulgrille was a bona-fide city. Under the provisions of the oharter of March 24, 1851, the municipal government was divided into three distinct branches--legislative, which was rested in a board of common oouncilmen and a board of aldermen, whioh together was styled "The General Council of the City of Loulaville;" the executive, rested in the mayor; and the judicial, in the city courts. The counclimen were elected for one yoar and the aldermen for two. There were eight wards --the charter limited the number of wards to twelve-and from each ward two councilmen and one alderman were elected, bringing the total to elght aldermen and sixteen councilmen. The mayor, who elso headed the police depertment, was elected for a term of two years. There was also a oity attorney, a treasurer, 
and an auditor, with a tax ingpector and collector for the Eastern and Western districts. Third street being ostablished the dividing line between the two for tax collection, sewerage, and other purposes.

The fudiciel department consisted of a city judge, attorney, clerk, and marshal, elected by the qualified voters of the city. The judge had jurisdiction in all criminal actions less than felony, with all the powers of a fustice of the peace in criminal and civil actions, and with the power of two sitting as a court of examination and commitment in felony cases. This was a great advance upon the old charter with a single legislative body, and without the confusion caused by the combination of executive and judicial power in the same body.

There were no fundemental changes in either the charter or the munioipal government during the period of the war, although the number of wards did increase to twelve by 1865, bringing the total number of aldermen up to twelve and the councilmen to twenty-four. In 1862 the Department of Fngineering was created, and in 1863 provision was made for the expansion of the police department.

1. 0.H. Stratton and John $M$. Vaughn, A Collection of State and Muniolpal Laws, Louisville: C Settle, 1857. pp. 71-125.

2. Johnston, $1,94$.

3. Council Records, No. 8. p. 47. 
Population, the life blood of ang clty, increased ateadily throughout the period of the war. In 1860 the city had a permanent population of 61,233 whites and 6,800 negroes, totaling 68,033 inhabitants. A yoar later the city directories listed 2,500 more names then the previous year, and in 1862--due to the influx of transients--the population had so inoreased that numerous advertisements for houses to rent were appearing in the columns of the locel newspapers. In the following year (1863) the Louisville Journal reported that, "there is a great demand for dwelling houses but a very inadequate supply." In a later isgue the same newspaper reported that the rents were rising higher and higher as the months went by--due to the laok of skilled workmen there was very little new con8 struction.

By the end of the war (1865) it was estimated that the population of the city had increased to 100 , -000 , or more than 33,000 in five years. The story of this increase in population can be told more

4. United Stater Census, Population. Intro Xv111.

5. See Tanner's Loulsvilie Directory for 1861.

6. Por instance, Loulavilie Journal, Ap. 7, 16, 1862.

7. Ib1d., Feb. 6,1863 .

8. Ib1d., March 9, 1862 .

9. Edward's City Directory, 1865. p. 77. 
eloquently by the assessed value of property during the war. The assessed value of real estate increased from $\$ 27,223,128$ in 1860 to $\$ 36,012,434$ in 1865 , and the total assessed value of real estate, personal property, and residuery from $\$ 37,330,921$ to $\$ 62,933,654$, an increase of more than twenty-five million during the same period.

III

The police protection of the City of Loularille seems to have been adequate during the perlod of the war, and there was plenty for the department to do. There were the usual crimes incident to a city; burglary, prostitution, drunkenness, and murder; and counterfeiters and gamblers were occasionelly arrested. Drunkenness and burglary seemed to predominate, although the newspapers often enough reported the finding of a dead man in an alley or on the street.

Onder the terms of the charter of 1851 the police force of the city was limited to one day watchmen and - two n1ght watchmen for each ward--all to be elected by the city council, so that it will be seen that the 9. History of the oh1o Fal1s C1t108, 1, 322-30. 10. Johnston, $1,104$. 11. For Instance, Loulav111e Journal, June 17, 1863. 
maximum police force thus provided for the protection 12

of the c1ty was forty-eight.

At the beginning of 1860 the police department consisted of a chief, a clerk, elght day polloemen 13

and sixteen night watchmen--there being eight wards--

who made an average of about six arreste per day.

Later in the joar, however, it became apparent that

the ofty needed a larger police force, and an ordinance

was passed by the General Council authorizing the

mayor and the chlef of pollce to employ "Deputy Marsh-

als" of the oity to do polloe duty as supernumery day 15

and night watchmen. During 1862 and 1863 many addit16

- lonal special police were elected until, in 1864 ,

there were fifteen day polloe and forty-five night

watchmen, costing the taxpayers approximately $\$ 40,000$ 17

per year. A year later (1865) the number had grown

to nineteen day police and fifty-nine night watch18

men, but curlously enough, despite the greater pro-

tection of numbers, the aggregate total of arrests

did not materially increase.

- 12. Stratton and Vaughn, op. cit., p. 89.

13. Tanner's Louiavilie DIrectory, 1860, p. 324.

14. Loulsvilie Journal, March, 1860. passim.

15. Counell Records, 10. 8, p. 258 .

16. Ibid..pp. 95, 132, 258.

17. Ibla., p. 258, 28i. Louigville Journal, July 10,1863.

18. Fawards Louisville DTrectory, 1865-66. pp. 154-5.

19. Louisville Journal, January, 1865. passim. 
Unt1l 1858, Louigrille's fire protection had been on a volunteer basis, but in June of that year the acore or more of volunteer fire departments, that had been a "problem to the oity authorities, but a joy to the rising generation," went out of existance to be replaced by a "pald" department--the second of its kind in the United States--consisting of five steam engines and one hook and ladder, drawn by twentythree horses and menned by sixty-five men, whose average yearly salary war $\$ 448$.

With the exception of the comeroil district the greater part of the city was built of inflammable materials, and the annual 1088 by fire to property owners--prior to 1858--had been almost beyond bellef. There had been instances where whole oity blocks had 23

been burned to the ground. After the re-organization of the fire department, however, it was estimated that "the number of fires has decreased more than throe-fourths.... and the 1088 of property is 1088 than 20. Wobster, 100. 01t., p. 132. 21. Loomis, George, Notes and Reminiscences of the Volunteer F1re pepartment or Louisvillo, TMS. in Filson Club Arohives 1919. HistoricaI sketch and Souronir of the Louisville Fire Department, (Publighor-?) p. 78. Deerling, op. c1t., p. 38. 22. Council Records, No. 7, p. 259. 23. Loulsville Courier, August 16, 24, 1853. 
24

one-eighth." The cost of mainteining the department

for that year - $\$ 21,702,86-$ was certainly a small

oum to pay for such a remarkable decrease in 1088 of property.

After 1860 the yearly cost of maintenance of the 25

department was approximately $\$ 30,000$, and it seems

safe to assume that the 208 s of property by fire fell

in direct proportion to the amount of money spent for machinery and man power; certainly the looal newspapers made no mention of an unusual number of fires. In March, 1862, the chief of the fire department reported but one fire with an estimeted 108 s of $\$ 75,00$, and during the month of June but three fires were re26

ported with an estimated 108 s of $\$ 500,00$. With the exception of the "Galt House Iire" in January, 1865, 27

with an estimated 1088 of $\$ 800,000$, there were no

large fires of ony consquence during the period of the war.

The year 1865 witnessed the beginning of a system of f1re alarm telegraphy, which was destined to assist in the subjugation of the fire element, more than any other agency yet produced. The system, known as the "Gemewell System," was installed by a 24. Deoring, op. c1t., p. 42. 25. Loulavilie Journal, July 10, 1863. 26. Councli Records, No. 8, pp. 139, 268. 27. Loulaville Journal, January 11, 1865. 
Mr. Kennard. There were fifty-one boxes, with one hundred and twenty-five miles of wire strung. The 28 first alarm was rung on hay 21, 1865.

By 1860 Louisville had lifted herself out of the mud. The greater number of her etreets were paved, it being estimated that there were sixty miles of pared streets and forty miles of paved alleys within the corporate bounderies of the city. Meny of these streets, however, were only covered with a thin costing of crushed limestone, were full of bog holes, and were almost impassible in bad weather. During the perlod of the war the hauling of supplies by conestoga wagons played havoc with the principal thoroughfares until, in 1862 and 1863, the oity fathers caused "stepping atones to be la1d across 31

many of the streets. In 1863 the newly created "Depertment of Engineering" sought to remedy the situation by using paring blocks and "boulders" on those streets which carried the heavy commercial 28. H1atorical Sketch of Loulavillo Flro Department, op. olt., p. 75. 29. DeerIng, op. cit., p. 35. 30. Louiavilie Journal, October 3, 1862. 31. Council Records, No. 8, pp. 103, 116, 231. 32. Ib1d., p. 47 . 
33

traffic. The used of crushed limestone, however, wa not entirely abandoned. In 1861 and 1862, many of the lesser thoroughfares were resurfaced by the relief labor furnighed by the city to relieve the unemployed meohanics and laborers. So intense was this relief labor thet the otreets were in much better condition at the end of the war than they had been at 35 the beginning.

But if the city had a right to be proud of the physical condition of her streets, she also had reason to be ashamed of the sanitary condition in which they were kept. Many streets in the outskirts of the city served as dumping grounds for domestic garbage, and one newspaper editor reported that, "the carcases of brace of dogs slaughtered by the police on Green etreet between Third and Fourth have become exceedingly offensive and should be remored 36

at once." Others served as "hog wallows" of polluted mud until, in the summers of 1862 and 1863, the ohief of polfce wasfo rced to announce that, "persons having hoge are hereby notified that the ordinance prohibiting the same from running at large will herem

33. Counc1l Records, 10. 9, p. 30 .

34. Ib1d., No. 8, pp. 73, 82, 89. Lou18ville Journal, Apr11 30, 1861; May 9, 1862.

35. Loularilie Journal, August $2,1864$. 36. Ib1d., JuIy 5, 1862. 
by/notified that the ordinance prohtbiting the same 37 from running at large will hereafter be enforced."

VI

Public hoalth seoms to have been generally good despite the unsenitary oonditions of the streets and the ravages of war. Sewers were almost non-existent, open ditches taking their place, but atill the local newspapers make no mention of an epldemic of any kind. Malaria wes becoming a thing of the past with the draining of the ponds and marshes within the 38 city, and the gradual disappearance of the city pumps foresaw the end of the cholera scares. The Loulsville Board of Health, consisting of one physician from each ward, saw to the health of the citizenry until the oity could proudly boast thet she was no longer "the grave yard of the West." The only disease the population had to fear was old age, or a knife or pistol in the hends of a drunkerd.

There was, of course, large number of wounded and 111 soldiers within the limits of the oity at all 37. Loulsville Journal, July 7, 1862; July 16, 1863. 38. Counc1l Records, No. 8, p. 52. 39. Edward's Louisville Directory, 1864, p. 71. 40. Louiaville Journal, January 8, 1863. 
times during the period of the war. The City Hospital, St. Joseph's Hospital, and other local institutions were unable to supply the demand for beds. In the Fall of 1862 elght of the ward achool bulldings were converted into hospitals by the militery, as were many 41

of the frotorles and warehouses. The Loulsville

Journal estimated that there were between 1,500 and 2,500111 and wounded soldiers in the various hospit42

als at all times. Due to the influence of the medical sohools and the Loulaville City Hospital medical attention was exceptionally good considering the period. The Iouisville Journal, in 1862, was able to report that, "the best medical and surgical talent of the 43

state has been devoted to our hospitals."

VIII

The "Mighty Ohio" had a perniolous habit of flooding in wrath every few years and disrupting the "orderly confusion" of Louistille's social end economic 41. Council Records, 10.8, p. 382. 42. Louisville Journal, Jan. 12, 1863; Jan. 3, 1864. 43. Ib1d., Jan, 6, 1862. When Louleville became headquarters for the Union army a large number of doctors in the state were brought into the c1ty to care for the 111 and wounded. 
11fe. The flood of January, 1861, which reached a height of 33 feet above the canal at the low water mark, and a height of 50 feet below the canal, left destruction and loss of life in its wake. The western part of the city was entirely submerged, and 8 s Anthony Trollope reported at the time: "At Shippingport... I sow the men and women and children clustered in the upgtairs rooms while the men were going about in punts and wherries, collecting driftwood from the river for their winter firing...the village amid the waters was a sad sight to see, but I heard no com45 a sad sight to see, but I heard no come plaints." But as the water continued to rise the anxious house-holders were forced to move to higher ground unt1l the Journal reported that, "the western section of our city is a desolete plece."

In 1862 the city experienced another flood, and although the water did not reach the height of the flood of the previous year, the Journal again report- that the water had covered Water street, and that the people were seeking refuge in other parts of the city. "All business is suspended," it was reported, "and houses ere being abandoned at the "Point." The 44. Loulsville Journe1, Januery, 1861. passim. 45. Trollope, A. A Hístory of North America, cited in History of the Oh10 Falls cities, 1, 323. 46. Iouisville Journel, Jan. 12, 1861. passim. 47. Ibid., Januery 17, 21, 24, 1862. 
better residential districts in the central and eastern parts of the city were not immune from the waters. On more than one occasion stately brick houses and "Iron inclosed lawns" were surrounded by the swirling waters. But floods were a matter of course to a oity whose life and trade was traditionally bound up in the river; the waters had no sooner subsided than the homes and warehouses were aga in occupied and life went on anew.

VIII

Lou1sville was one of the few cities in the West hoving a horse drawn railroad. The cars were small and were "drawn by a single horse or mule--very small and of the bob-tall variety." The tracks extended from Twelfth atreet to the wharf and ferry landing at Portland; and at Twelfth street a line of omnibusses connected with the cars "and ran to the upper end of the e1ty on Main street." belonged to the same company, and they "carry pass48. There were $1100 \mathrm{dg}$ in 1863 and 1865 but they did not reach the height of those of 1861 and 1862 . 49. Johnston, 1,327 . 50. Deering, op. cit., p. 37 . 
engers the whole distance, from Wenzel street to Portlend--five and half miles--for ten cents. A person can ride from one end of the omnibusse route to the other--two miles--for five cents, and also in the cars from Twelfth street to Portland--three and one-helf miles--for five cents." 51 The cars ran every half hour. The greater part of their hauling--passenger traffio being limited--was river freight from the whare at Bortland to the city wharf on water street. By 1864 this hauling had become so profitable that the "Loulsville City Rallroad Company" was organized, and in 1865 the "Central Passenger Rallway Company" was chartered to carry passengers and ereight within the city. Thus at the end of the war Louisville had three distinct rallway companies either hauling, or preparing to heul, freight and passengers within the limits of the eity.

IX

Prior to 1860 the water problem had bocome acute

51. Deering, op. cit., pp. 37-8.

52. The city wherwes in the district which is now bound by second and Seventh streets.

53. Johnston, 1,327 . 
in Louisville. The good house-wives were forced to trudge to "the strateglcally located city pumps at the corners of the principel streets which were the only public dispensers of drinking water." Although these wells wore from forty to fifty leet deep, and the pumps were made from pine logs twelve to eifteen inches thick that were easy to operate, many householders, rather than carry water a distance, resorted to wells and cisterns built in their own back yards. In 1856 the Loulaville Water Company was organized "to furnish pure water to the citizens of Loulaville." But 1t was not until 1861 that water 55 first passed through the mains. In that year, Chas. Hermony, the superintendent and ohief engineer, was able to write that, "the principle of order and bequty, ever inseparable from utility, pervades the work from end to end..." The pumping atation was of the "Corinthien order of arohitecture," and "possessed an individual beauty that is rarely met with, being delicately harmonious in proportions, and at the same t1me, grend and imposing in effect." This "great

54. Summers, W.T., Rominiscences of 1858 to 1818 in Louisville, (Ms. In Filson Club Archives) 1919. 55. Construction was actually comploted in Aug. 1860. 56. Annual Report of the Louisvillo Water Company. 57. Ibid., 1862-63. 
water-works" we: as "susceptible of being beautified and embellished as a park to en extent that will rival, if not pass, anything in the American landscape gardening..." The reservoir held enough water for 26 miles of pipe in the city and for some 100 fire cisterns mointeined by the fire department. But in spite of the princlple of order and beauty, "ever inseparable from utility," the undertaking proved not so successful as the promotors had hoped. "The past year (1861) has been one of unprecedented gloom and approhension," wrote President Harris in the annual report, "simultaneously with the turning of water into the city commenced that erightful political panic which, over-spreading the whole country, culminated In a dreed Civil war, which has disturbed and deranged -very branch of business, and created such generel distrust of the future that few have lelt safe in making any further outloys; all have retrenchod their expenses, dispensing with everything that could be done without... and owing to the state of the public mind the patronage of the waterworks has not been so great as it otherwise would have been." But the war 58. Annual Report of the Louisv1lle Water Company, 1861 . 59. Ibid., 1860, 1862 . 60. Ib1d., 1862. 
was not the only catastrophe that faced the littlo company in its first days--the system leaked from end to end. 61

Although the company made substantial gains in 62 new customers from 1862 to 1865 , the majority of citizens continued to get their drinking weter from the olty pumps, "which afforded cheap, pure, and abundant supplies of water fit for a prince."

During the decade prior to the Civil Wer Louisville's public schools had made great strides forward. The educational leaders of the city had succeeded in erousing the public to a sense of educational need until, in 1860, public funds were? - supporting ten primary and gramner schools, one "Female High School," and the Male High School." Out of a totel population of 68,033 there were approxImately 12,000 students attending the greminer end high schools. Classes were held in brick and wood buildings, 80 by 100 feet sure, each being 61. Courier Journal, Mag. Section, Nov. 28, 1937. 62. See Annuel Reports, $1862-65$. 63. Deering, op. cit., pp. 36-7. 64. Ibid., p. 42. 65. Ibid. 
occupled by 700 to 800 children. The teachers were paid an aggregate salary of approximately $\$ 4,700$ each 66 month.

In the field of private and denominational 67 education there were six Catholic parochial schools, two commercial schools, the Cedar Grove (Catholic) and Presbyterien Femele Academies, Mr. Butler's private school for girls, and Misses McBurnie and Womack's for boys, and several others, besides Bishop Smith's and the Rev. Mr. Beckwittes girl's schools 68 in the vicinity. The city was indeed able to supply both elementary and secondary educetion. In the field of higher education, the University of Louisville and the Kentucky Medical College supplied training in the professions of law and medicine. After the beginning of the war the educational advencement of the city was seriously hampered. As early as December, 1861, the Board of Iducation was forced to deny rumors thet the schools would close becruse of monetary difficulties. The 66. Loulsville Journal, Jan. 7, 1861. Deering, op. c1t.. p. 42. The city spent aproximately $\$$ \% 000 yearly.

67. Johnston, 2, 115-32. 68. Deering, op. cit., p. 43. 69. "Origins of the University of Louisville," W.C. Mellalliou, Filson Club History Querterly, Vol. 12, No. 1, Jan. 1937. pp. 25-41. 
Loulsville Journal reported that, "according to the report of the Finance Committee, the schools have never in any former period of their history experienced greater prosperity then they enjoy at the 70 present time." But if the schools were not suffering from monetary difficulties they certainly were suffering from lack of attendance. In April (1862) the principal of the Female High School reported thet the average deily attendance wes but sixty-five, and in the same month the rule apportioning forty71

five pupils to a teacher was suspended.

Shortly after the schools were opened in september, 1862, Loulsville was placed under martial law and the schools were forced to suspend, as the ward school buildings were "seized and converted into -hospitals for the invelid soldiers by the Federel authorities." An effort was made by both the school Board and the municipal governnent to get the order revoked, but General Boyle refused to reoant the 73 order. He did, however, permit the school Board to 74 use the two high gchool buildings. Twelve of the

70. Iouisv1lle Journel, Jen, 7, 1862 .

T1. Ib12., April 8, 1862.

78. Ibid., September 23, 1862. The schools were officially closed on september $22,1862$.

73. Summers, Loc. c1t., p. 11. See also report of G.W. Morr $\overline{18,} 1 \overline{862}-3$.

74. Council Records, No. 8, p. 52 . 
larger churches in the c1ty came to the rescue of the school system by offering their "Sunday school rooms" 75

as temporary class-rooms; but as many of these rooms were in damp basements the "School board found it imposstble to make use of them," and was forced to rent empty bulldings and store-houses in order to have satisfactory number of school rooms. Because of this added expenditure the salaries of the teachors were reduced and it was again found necessary to suspend the rule requiring of each teacher an average of forty-five pup1la. It was estimated that the daily attendance for the yeer 1862 wes cut almost in half.

The public schools never fully recovered from this setback during the period of the war. Although classes were not suspended after 1862, the ward school buildings were not recovered until after the end of the war, and attendence never reached normal during the period. In 1865, however, an attempt was made to improve the condition of the schools by submitting to popular vote proposition to increase the school tax from five to twenty cents on the \$100. The proposition was carried by a mejority of

75. Louigville Journal, Sept. 27, 1862; 0ct. 22, 1862. 76. Report of G.W. Morr is, 1862-63. 77. Louisville Journal, December 23, 1864. 
more than 25,000 votes and Louloville picked up where she had left off in 1861 .

$X I$

The five years of the Civil War saw the tranaition of louigville from a frontier town to a cosmopolitan city. During the normal course of events the population increase of the city had been approx- Imately 2,200 per year; but during the period of the wer the increase was more than 4,500 per year, while after 1865 the increase returned to normal, or approximately 2,000 per year.

The physical growth of the city was in direot proportion to the increase in population. Where in the ten years prior to the war the number of city -wards had only increased from six to eight, the five years of the war saw an increase of from eight to twelve, or a gein of more than two-hundred per cent. There was a like increase in property valuation from $\$ 36,012,324$ in 1860 to $\$ 62,933,654$ in 1865 .

78. Johnston, $1,233$. 
What was true of the physical growth of the oity was also true of the various departments of the municipal government. The personnel of the police department incressed by more than seventy-five per cent, and the fire department by more than fifty per cent. The engineering departrent was established and saw to the regurfacing of practically all the streets, as well 28 to the construction of many new thoroughfares, while sidewalks were constructed, sewers dug, and the ponds and marshes within the city drained. It is probable that the city witnessed more changes for the better within the five years of the civil war than woula have normally taken place during a quarter of a century. 


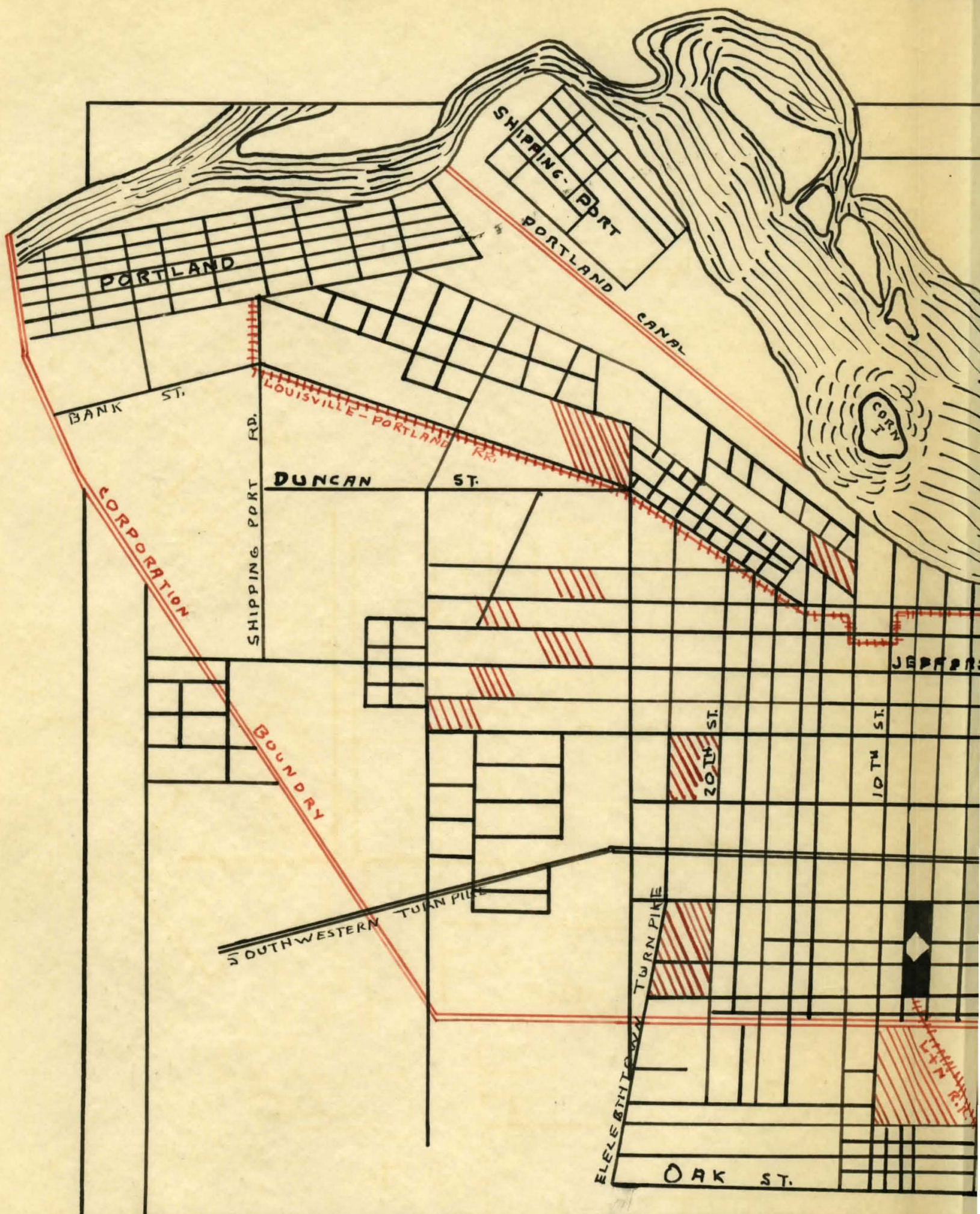

SCAL 
THE GROWTH OF LOUISVILLE, 1860-1865

\section{THE CITY LOUISVILLE 1865}

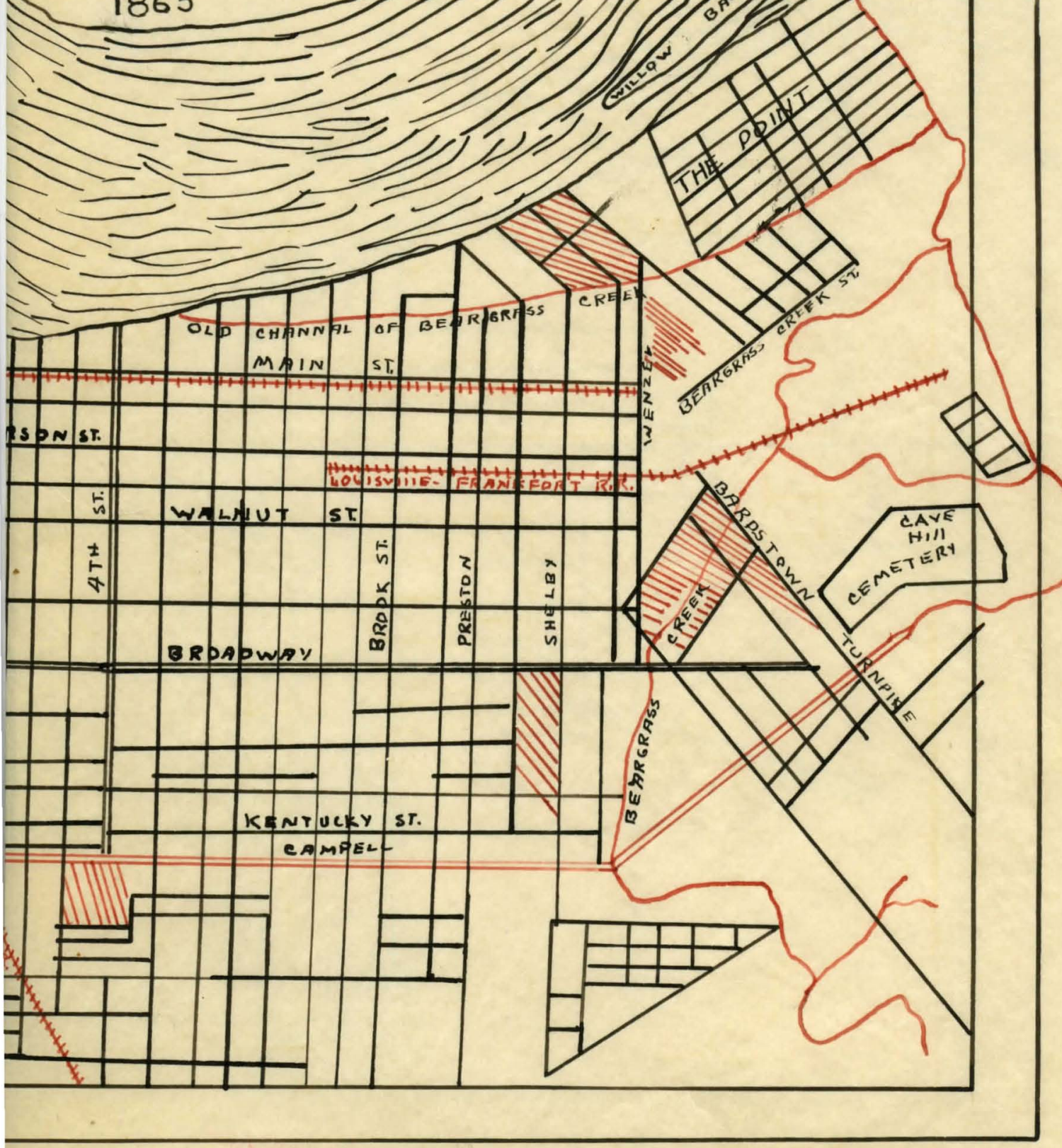

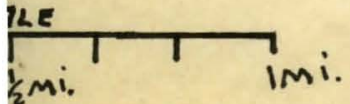


TRADE AND ECONOMIC DEVELOPMTUT

During the latter part of 1860 and the early months of 1861 Loulsillie's trade with the South was 1

booming. Due to a poor crop season in many of the Southern States, as well as a frenzied effort on the part of the Confederacy to stock up for the coming conflict, comercial activity had never been more brisk. Her(Kentucky) flour and mechinery, bagging and rope, jeans and lindseys, segars and manufactured tobacco, cendles and soep, agricultural implements-manufactured within her limits--brought into her lap the rast $\frac{\text { sum }}{2}$ of twelve millions of Southern gold annually..." And Louisville, by virtue of making her- self a "great collecting center for commerce" for both Kentucky and the North, became the mistress of this trade to the South. The Iouisville Journal reported that there was not an empty warehouse to be found in the city, and thet so much freight ceme in by wagon, steamboat, and railroad, that the streets in the

1. Louisville Journal, October, 1860. pasaim.

2. Louisville Courier, May 1, 1861.

3. Louigville JournaI, May 14, 1861. 
city (wholesale district) were soon jammed and much material had to be left in temporary depots on the outskirts of the city. The Louloville and Neshrille Ra1lroad, which bore the brunt of transportation, carried it southward in an never-ending stream. There were more goods than the road had capicity to 6 trensport, and the company was forced to lay an embergo on through freight, as well as advertise in the local newspapers at what hours each dey the road would accept out-going freight at the depot. The envious Cincinneti Gezette felt orlied upon to comment that, "day and night for weeks past, every avenue of approach to the depot has been blockaded with vehicles waiting to discharge their loads, while almost febulous prices have been paid for hauling, and the road has taxed itself to the utmost oapacitieg to carry through the enormous quanities of freight delivered to $1 t^{8}$

James Guthrie, President of the Louisville and Neshville Railroad Company, reported at a public 4. Coulter, op. olt.,p. 60. Journal, May 1\%, 1861. 5. Ibid., pp. 60-6I.

6. Loulsvilie Journal, April 30, 1861.

7. Ib1a., Key 16, June 3, 1861 .

8. Cincinnat1 Gazette, June 1, 1861. It was estimated that the Loulsville and Nashville Carried more than four-hundred cers of foodstuffs southward each day. 
meeting in April, 1861, that, "during the latter part of July last (1860), and extending through the months of August and september, more provisions came to the I \& $N$ depot than the road had capacity to transport.. and the river hed \& full share of the southern trade." From October to December (1860) there was a decline in Ireight receipts from $\$ 54,000$ to $\$ 22,000$; but beginning with February, 1861, there began an increase 10 which leeped from $\$ 23,000$ to $\$ 68,000$ in June--this freight increase was not composed of foodstuffs as the 11 road averaged but oight carloads per day-- and virtually all of this trace was going southward; as the company stated, "of the through business proper, between Louisville and Neshrille, 93 per cent. of the revenue was from freights received at Neshrille, and only 5 per cent. from thet forwarded or originating at Nashville. Hence, of every one-hundred cars loaded at Louisville for Hashville, ninety-five were returned empty; that 18, the Company performed 95 per cent, of the train service northward for through business or $47 \frac{1}{2}$ per cent. of the wholo without com12 pensation.

There 1s no way of knowing what percentage of 9. Louigvillo Journal, ApriI 30, 1861. 10. Annual report of the Directors of the I \& N Railroad Company, 1861. p. 21 .

11. Louisville Journal, April 30, 1861.

12. Annual Roport, loc. c1t., p. 19. 
this freight was munitions of war, but from news items and accounts the amount must habe been tremendous. In January, 1861, the Iouisville Journal reported thet in one day "there was loaded on trains going to the South, 382 balls, elght inches in diameter, 60 pounds each; 232 balls, eight inches in diameter, 60 pounds each; 800 balls, 42 pounds each; 348 shells, eight inches in diameter, 60 pounds each; and 1000 kegs of powder, 25 pounds per keg." On the same dey the Louisvilie Democrat published an editoral which lambasted those "blood suckers" who persisted in furnishing munitions of war to the 14

states in rebellion.

It is evident that contraband trede was moving southward in an ever increasing stream. Huge profits were to be made by those who felt no "fear of the God or government," and it seems that the greater part of the Louisville merchants felt nelther. Easy money fore-shadowed all thoughts of the future. Every gun shipped southward meant a hundred per cent profit, and 8 s one Louisville merchant expressed 1t; "A hundred dollars is worth more to me than a hundred years in hell." So meny of the merchants felt the same way that Prentice felt forced to ask what was to "become of the guns that are being consigned to 13. Louisville Journal, Jan. 31, 1861. 
Mudaraugh's Hill, "14

As long as there were no ectual hostilities this trade in munltions seems to have been tolerated, if frowned upon, "by the patriotic in the North as well as by the Federal Government;" but with the firing upon of Fort Sumter, the Union States of Illinois, Ohio, and Indiena, took matters into their own hands and made strong efforts to halt the traffic. In May, 1861, Governor Dennison of Ohio "ordered railroads and express companies to searoh all commerce going in the direction of a seceeded state and to seize all contraband articles." This order, directly aimed at Louigville, caused great indignetion in the city. The Louisville Courier went so far as to head an erticle, "TO ARMS! TO ARUS: CINCINNAT I SEIZES SOUTHERN PROPERTY! Kentucky will you stand back? Kentuckians are you ready to submit to choins and slevery, or will you assert your rights with 16

arms in hand?" And some person or group in the city caused a condensed version of the article to be printed in German and circulated among the large German populetion."

The State of Indiana made virtualiy the same restrictions, and the Surveyor of Customs at Jefferson14. Louisville Journal, June 27, 1861. 15. Coulter, op. cit., pp. 61-3. 16. Louisvilie courier, April 18, 1861. 17. Louigville Journal, April 22, 1861. 
ville refused to allow provislons to oross the ohio River to Louisville. Governor Yates of Illinois, folifing the example of Indiana and ohio, caused a tight blockade to be placed around the junction of the Ohio and Missiseippl rivers at Cairo.

This policy of trade restriction on the part of the three above mentioned states had a two-fold effect upon the city of Iouisville and its inhabitants; it served to limit considerablely Louisville's trade with the south, as it cut off the supply of raw materials which the South was demanding, but at the same time it increased tremendously the smuggling of contraband goods. The blockading of the river at Cairo virtually halted 20

all river traffic, es ceptains on south-bound vessels were required to secure special licenses for their steamers, and goods could not even be shipped to Columbus (Kentucky) unless it could be proven thet the consignee 21

was loyal. These embargoes did not effect the railroads, however, as the Federal Government deemed it unwise to antagonize Kentucky in that respect and shipment by rail went on apace.

But on Mey 2, Salmon Chase, Secretery of the

18. Louigville Journal, May 2, 1861.

19. Ibid., May 4, 186I.

20. IbIa.

21. Colonel Prentice to Simon Buckner, Rebellion Records, Document, 1, 194. 
Treasury, seelng that all goods leaving Louisville would eventually reach the Confederacy, declared an embargo on all goods going southward. Very little effort was made, however, on the part of the custom officers, to enforce the rules; and then too, the Louisville merchants, as well as those people in sympathy with the Confederacy, soon found ways to evade the blockede. As the Journal reported, "munitions are constently consigned to Kentucky towns bordering on Tennessee, "and $n^{\text {it }}$ is not uncommon for women to convey revolvers under their hoops to the south." When on June 21 (1861) the Surveyor of Customs at Louisville announced thet after the $24 \mathrm{th}$. no shipments would be allowed over the Louigville and Nashville Railroad without a permit from his office, huge amounts of contrabana were hauled by wegon to points south of Loulsville where there was no oustoms agent. The goods were then logded on trains and consigned to towns on the Tennesgee line--notably Franklin and 27

Hadensville. As time went on, the more bold, not oaring to go to the trouble of transporting goods out of the city before loading, merely concealed contraband in legitimate consignments, or, in some cases,

22. Louisv1lle Journel, May 4, 1861.

23. Ib1d., Apr $1127,1861$.

24. Ib1व., May 20, 1861.

25. Collins, Kentucky, 1, 92. Journal, July 29, 1861. 26. Louigvilie Democrat, July $7,1861$.

27. Loulsville Journal, July 24, 1861. 
28

forged government permits. Thus trade in munitions and contraband went on apace, and many a prominent Louisville merchant made a fortune during the period.

But by the first of October, 1861, due to heavy fighting in both the southeastern and western parts of the State, it became almost imposaible to safely deliver large amounts of goods to the Confederacy and the trade begen to decline. The Journal, although not in sympathy with smuggling, deplored the fact that 29

Louisville wa experiencing a depression. A greator part of the manufacturing industries were forced to olose down, and most of the business houses were forced 30

to "retrench their business." The entire winter was

a perlod of "business depression and despondency." A charactertio news item sald, "our wharf in a business point of view, presents a very disconsolate appearance."

In Meroh (1862), however, the Journal was able to report that, "with the returning of spring, and the fading away to the far South of the Rebellion, leads to the belief thet there will be on almost immediate 32

resumption of business..." And in later report, "Iivestook is selling better than it has in years...all 28. Loulsville Journgl, January 12, 1863. 29. Ib1a., October 19, 1861. 30. IbTa., November 6, 1861. 31. Cincinatt1 Commercial, October 31, 1861. 32. Iouigv1Ile Journal, March 12, 1862. 
the people too, seem to be fond of the Iincoln ourrency." These reports of the Journal were not over-optimistic, for when Nashville and Chattanoaga and points in Georgie became the scene of active operations, then "Louisville became the great source of supply for the armies, and the Louigville and Neshville Railroad the ohief reliance for communication with the front." The city became vast depot for army supplies of all kinds, and the base of supplies for both men and stores unt1l, in January, 1862, the city assigned two special policemen to protect the merchandise lying at the wherf.

The Journal rejoiced in the fact that "the opening of the tobacco trade between Louisville and northern Tennessee is one of the first fruits of the success of the Federel ermies...no less than 44 hogsherds were received yesterdeg." "Trede with many areas in the South was unrestricted, and by the latter months of 1862 Louigville had assumed her "ante-bellum commercial appearance. Cotton which was selling for eight cents per pound was arriving dally. The tobacco market, which had no outlet in New Orleans, wes steadily advencing until, in soptember, 1862, the grades sold at 10@32, and as much as 35036 was paid at times. The pork market was also expanding until 500 hogs were slaughtered each 34. Iouisville Journal, Nerch 17, 1862. 35. City Journal, No. 8 , p. 229. 36. Louisville Journal, March 15, 1862. 
dey during the killing sesson.

But the greatest factor in the revival of trade and commerce was the huge letting of government contracts for foodstuffa and army supplies to Louls37

ville merchants. The Journal reported that all

livestock "has been sold a fast as they arrive... and -. the purchase of cattle for government use has been 38

good." It was not uncommon for \& Louisville merchant to get a forege contract "ernbrecing 10,000 tons of hay; 200,000 bushels of oats; 200,000 bushels of corn." or a contract for " 6,000 head of beef cattle, to be delivered each week." 40 one Loulsville contractor furnished Grant with 200 cattle daily. "The imrense distribution of ermy stores," it was reported, "gives employment to a very large number of men, and contributes much towerd the relief of the poorer classes of people. Many of our business men are also coining money by supplying the many necessities of the large army now within the state." And the Journal was able to report at the beginning of the new year (1863) that, "the business of the year (1862) has closed very satisfectorily. It is true that operations in an ordinery

37. Louisville Journel, Nerch, 1862. passim.

38. IbId., March 19, I862.

39. Ib1d., Nerch 11, 1862.

40. Ibld., July 2, 1862.

41. CInciradti Commercial, Nov. 5, 1862.

42. Ib1d., Decernber 23, I862. 
way have been for the most part limited, but the government has been a large purohaser in this market, and prices of the leading articles of produce have been high, and transactions have been upon a cash basis."

From 1863 until the end of the war Louisvillo's trade continued to prosper. The merchants continued to receive government contracts, and trade with the South was steadily expanded unt1l it was reported thet "the blockading of the streets south of York 18 so great by teamsters that coal wagons cannot get through." And, "there are at present awaiting shipment 60 carloads of private freight thet w1ll be sent forward a repidy as the road will permit." ${ }^{45}$ The Louisville and Frankfort Railroad, which was occupied mainly with hauling frelght into Loulaville, reported that there was an increase in Ireight recelpts over those of 1862 due to trangportation 46 of government stores. In Maroh (1863) a new reservolr of produce was tapped when the Loulsville Journal reported that "many of the restrictions upon trade between Iouisville, New Albany, and Jeffersonville have been removed. A lew articles palpably contraband are excluded from commerce between the three cities."

43. Louisv1lle Journal, Januery 5, 1863.

44. IbId., Tebruary II, 1863.

45. IbTd.; Januery 5, i863.

46. Annuai Report of the Loulsville and Frankfort Ra1lroad Company, 1863. pp. 3-4.

47. Louisvilie Journal, March 14, 1863. 
Not all of Louisville's trade, however, was going southward. Because of the embargo laid upon the Southern states much tobacco and cotton was shipped to Loulsvilie where it was sold upon the open market 48

to Northern buyers. The tobacco market had its biggest season in history, selling a total of 63,326 hogsheads of leaf ranging in price from 230 for average grades to the extreme price of 560 for premium wrapper. The market speculators reaped a hervest, and large fortunes were rapidy made all through this exciting period. There were also great losses to venturesome traders. One hogshead of clarkeville wrapper was bought for $\$ 152,50$ per hundred, but when resold in New York in 1866 only $\$ 15.50$ was paid, a net 1088 of $\$ 7,000$ on the one package.

Tabulated list of tobacco sales

\begin{tabular}{|c|c|c|c|}
\hline & Hhds. & & Hhds. \\
\hline $\begin{array}{l}1850 \\
1855 \\
1860 \\
1861 \\
1862 \\
1863\end{array}$ & $\begin{array}{l}\cdot \quad \cdot \quad 17,500 \\
: \quad: \quad 11,594 \\
: \quad: \quad 17,505 \\
: \quad: \quad 20,823 \\
: \quad: \quad 38,908 \\
\cdot \quad 36,717\end{array}$ & $\begin{array}{l}1864 \\
1865 \\
1866 \\
1867 \\
1868 \\
1870\end{array}$ & $\begin{array}{l}\cdot \quad 63,326 \\
: \quad: \quad 44,210 \\
: \quad 35,927 \\
: \quad 34,218 \\
: \quad 29,508 \\
: \quad 22,201 .\end{array}$ \\
\hline
\end{tabular}

What was true of the tobacco market was also true true to a lesser extent of the cotton, hog, and cattle 48. Louigrille Journal, Feb. 16, 1864 . 49. Johnston, $1,255$. 50. History of the Ohio Falls Cities, 1, 337 ff. 
markets. Cotton was bringing 30050 with a heavy demand, and one local meat paoker had no trouble filling a government contract for 10,000 hogs. The Cincinnat1 Commercial estimated that more than 1000 hoga were slaughtered each day during the killing 52 season. On the whole it was estimated that "there were $\$ 2,500,000$ transactions in tobacco; provisions $\$ 10,000,000$; drygoods $\$ 12,000,000$; Plour and grain $\$ 4,000,000$; and $\$ 10,000,000$ worth of hoge."

There was a general falling off of commerce to the South in 1865 due to the collapse of the bankrupt Confederaoy, but the Louisville merchants had so corraled the market that they dominated the southern trade for more than generation and subsquentiy reaped harvest during the "Reconstruction" period.

The decade from 1850 to 1860, and until the Civil War began, was the period of the greategt development in river trade and travel. The enterprising copital51. Collins, Kentucky, 1, 145. 52. Cincinnat1 Commerciel, Deo. 5, 8, 24, 1861. 53. Edwara's Louisvill Directory, 1864. pp. 73-4. 
ists of Loulsville had steamboats of "unrivaled excellence, for pessengers and freight, running upon the Ohio and the Mississippi, while suitable packets plied on the Cumberland, Tennessee, Arkansas, Yazoo, and Red rivers, carrying her (Louisville) manufactures and merchendise to all points, end gathering in their products, either for home consumption or for shipment eastward." This traffic, which hod early felt the squeezing effects of the war with the seizing of the river vessels for army service, end by the blockeding of the rivers by both the Confederate and Union armies, was the last to feel the welcoming effects of the revival of trede.

Where it had been common for the "river news" of 1860 to list twenty or more boats "lying at the wharf," it was exceedingly uncommon in 1861 for a river bulletin to list more than five depertures or arrivals in 2 single dey. But during the latter part of 1861 and the early month of 1862 the river began to feel "a fow flickering signs of her former commerce, as she (Iouisville) was able to secure boats now and 54

then." When the Confederates were driven from the state river trade immediately began to improve. "With peans of self-praise, she (Louisville) sought 54. Coulter, op. cit., p. 244 . 
to wean the western Kentuckians from their Confederete llesh pots." She wanted their tobrcco and other produce and they were invited to "come to the safer and more congenial market offered by our city, the reputetion of whose merchents is without a blemish, and whose capecities for supply ere without a successful rivelry in the great basin of the West."

Although western Kentucky never deserted the Confederacy, it sent Louisville enough trade to give her cause to sey three months later thet her wharf was "completely blockaded with the tobacco, cotton, and corn brought up from below by the Henderson and Cumberland river boats." On January 8, 1862, the "W.W. Crawford" arrived from Henderson with 1,500 bushels of wheat; 150 berrels of apples; 45 barrels of beans; and 11,000 hoop poles, all for reshipment 58

to Cincinnat1. Trade gradually increased unt1l, in July, 1862, the Louisville Journel, was able to report the arrival of nine vessels in a sinzle day-the Nashrille bringing 120 beles of cotton, and the 59

other boats with lesser cergoes.

But the river seemed doomed to suffer all sorts 55. Coulter, op. cit., pp. 243-5. 56. Loulsvilie Journel, Feb. 17, 1862. Editorial. 57. Loulsvillo Democrat, Mey 3, 1863. 58. Tourgville Journe , Jen. 8, 1862. 59. Ibid., July 19, 1862 . 
of obstructions. No sooner had traffic been opened as far south as Knoxville then the river was closed between Cincinneti and Louisville by orders of General Burnside. The river was an important highway for the army traffic and it quickly became the target of the Confederate armies and raiding parties. Even after the Confederates were driven from the state, the guerillas became menace to river traffic as they sought their individual plunder. "John Morgan as well as Forrest took especial dely ght in hitting the state like a thunderbolt and leaving consternation and destruction in his tre11." The former, in the sumner of 1863, so completely disorganized the traffic on the Oh10, that Burnside forbade steamers to ply between "Cincinneti and Louisville without permission and ample protection."

But with the Fell of Port Hudson the Mississippi River became open to navigation, and there was "great rejoicing in Louigville. The Louigville Journal visloned "heavy laden river boats once more at New 61 Orlesns." On July 22, 1863, the Louisville Democret announced: "With a glow of satisfection we inform the public thet a boat is loading for New Orleans." By 60. Coulter, op. c1t., p. 243. Offlciel Records, ser. 1, vol. 31, Part 1, p. 798. 61 . Loulsvilie Journal, July 11, 1863. 
the latter part of December (1863) the trade with the river towns was fatrly well established, and many families were returning to Louisville... running the blockade from Holly springs to Memph1s." And on December 24 (1863) the first cergo of molasses and sugar, since the beginning of the war, arrived in Louigville from New Orleans.

The river trade was never completely freed from restrictions until the war ended, and by that time a "new era had begun which shifted commerce to the railroads and mede the glory of the river a tale that wes told." On July 2, 1864, Congress imposed a few minor embargoes on Southern trade. Yet the river news of 1864 and 1865 , showed that trade was active. A boat from the Kentucky River carried to cincinnati -w1th reshipment at Louigville-- 2,866 sacks of wheat, 272 bags of berley, 100 sacks of hemp seed, 138 barrels 64 of flour, and 60 packages of merchandise. Later bulletins showed steady arrivals with heavy corgoes.

III

In 1860 Loulaville was well on her way to becoming 62. W1II (Ietter in Filson Club Archives)

63. Collins, Kentueky, 1, 139.

64. Cincinnati Gezette, Jan. 10, 1865. 
one of the leading menufacturing conters of the West. Her 436 factories, employing 7,396 hands, with $\$ 5,023$, 491 capital employed, paying out $\$ 2,120,000$ annually in wages, and turning out products worth $\$ 14,135,000$ each year, ranked her twelfth among the manufacturing 65

cities of the nation. Mass production and the assembly line were generally unknow, most of the Inquatries being small home owned affairs employing from five to twenty hands. There were a few large Industries, however,--notably tobacco and foundries-employing as many as four-hundred hands.

The first six months of the confliot played havoc with Louisville industry. A great number of the manufactures were suspended and remained so for the 67

duration of the war. "Our factories," it was reported, "have been made into barracks by the army." A lew industries, however, such as clothing, foundries, steamboat transportation supplies, tobacco, and provision factories were given a great impetus by the demand for army supplies.

In 1860 there were 21 clothing establishments 69

employing 800 hands, and in 1864 the number had Inoreased

65. Onited States Consus, 1860. Manufacturing. p. 180. 66. Ibid., pp. 180-1.

67. Loulavilie Journel, January 2, 1861.

68. Ib1d., 00tober 9, 1863 .

69. United States Census, 1860. panufacturing, p. 180. 
to 56 establishments employing 1,400 hands. In 1863 the Loular1110 JournaI reported that many empty warehouses were being converted into clothing faotories, and that skilled needle-workers were almost impossible 71 to find. The iron industry grew from 9 foundries in 72

1860 employing 511 hands to 20 industries in 1864 73

employing 1,200 hands. The tobacco factories grew 74

from 10 in 1860 employing 537 hands to almost 100 in 1864 employing 1,500 hands. The provision factories 76

too, more than doubled.

With the above exceptions, however, the greator number of the industries ritually ceased to exist. The breweries were only able to operate part time as the 77 army consumed most of the grain, and there was little demand for agricultural implements. The soap, candle, furniture, cordage, glassware, and carriage factories found it impossible to dispose of their products and were forced to close their doors. By 1864 the proponents of "A Greator Louispille" had given up all hope of making the city the industrial center of the Weat and South, and were preforce content to advertise the city as a "commeroial rather than a manufacturing town." 70. CampbeII's Business DIrectory, 1864. p. 35 . 71. Louisrilie Journal, Jenuary 30, 1863. 72. United States Census, 1860. Menufacturing. p, 181. 73. Campbell's Business Direotory, 1864. p. 35. 74. Census, 1860. Manufroturing, p. 181. 75. Campbeil's Business Directory, 1864. o. 35. 76. Ibid. 77. Loulaville Journal, May 10, 1863. 78. CampbeII's Business Directory, 1864. p. 35. 
The Loulgrille banks showed great strength and stability through-out the perlod of the war. Although the dally money-market report usually read, "The benks were doing very little yesterday beyond renewals, and the street capitalists too, were doing nothing in a manner, " the bankers saw fit to establish three large benks in the city between 1861 and 1864, raising the total number from 7 with an aggregate capital of $\$ 5,310,000$ to 10 with an aggregate capital of more then $\$ 7,000,000$.

"The suspension of specie payments by the banks of the large commercial'centers in the East" in no way effected the banks of Louigville, as they continued specie payment even after the Federal Treagury Department had advised a suspension. Even after Governor Magoffin had signed a bill in April, 1861, authorizing Kentucky banks to issue notes of denomination under five dollars and to suspend specie payments in certain contingencies, the Louisville Journel was able to announce more than a year later that, "The Louisville banks are redeeming their noter 79. Louisville Journal, January 4, 1861; Ibid., November, 1862. passim.

80. Edward's City Directory, 1864. pp. 117-18. 81. Louisville Journal, January $6,1862$.

82. Collins, Kentucky, 1, 119. 
83

In United States Treasury notes or in specie." These same notes were running at par a year after the war had started; in 1863 they were bringing a 5 per cent. premium oxer United States currency at Cincinatti and a greator or legs adrance in meny other places. 84 Throughout the war they were bankable at par in the leading financial centers of the country.

The bank stock market was strong throughout the period, the stocks of most banks standing at par or better with a few minor exceptions. In 1861 dividends 87

stood at about 4 per cent; in 1862 there was a falling off to about 3 per cent. due to the lack of confidenoe 88

in business generally; but from 1863 through 1865

89

dividends stood consistently around 4 per cent. These comparatively good dividends were due, of course, to the rapid turn-over of bank loans as a result of army contracts.

\section{V}

If fortunes were made by those comparatively lew

\footnotetext{
83. Louisville Journal, Jenuary 6, 1862.

84. History of the Ohlo Falls Cities, 1, 327. Collins, Kentucky, 1, 119 .

85. Ib1d.

86. Ibla., p. 328. In 1863 the stooks of the Bank of Loulavilie and the Bank of Kentucky were bringing $\$ 96.00$ per share.

87. Louisville Journal, Jenuery 6, 1862.

88. Ib1d., January 4, 1863.

89. Collins, Kentucky, 1, 139.
} 
90

lucky ones who dealt both in legitimate and contraband commerce during the war, the same cannot be said for the laborers and "mechanics" of the city. Theirs was a time of much suffering and fasting, reliered only occarlonally by a small dole from the city fathers, or by paokets of food and clothing supplied by their more fortunate neighbors.

In 1860 there were 7,396 men and women employed 91 in the various manufacturing industries, and still greater number employed in the "stores, warehouses, transportation, hotels, and coffee houses; as domesties, and in other industries employing labor." 92 Due to the demand for manufrotured goods in the South, as well as by the huge shipments of goods that were passing through Iouisville, work was to be had by all those who wanted 1t. Wages were fairly high, ranging from $\$ 1.50$ to $\$ 2.00$ per day for mechenics and laborers, and $\$ 5.00$ per week or lese for domestics, clerks, etc. The Journal reported that the people of Loulerille were "enfoying $800 d$ times...money is plentiful," and the other 1008 papers reflect nothing but prosperity.

But with the actual outbreak of war the picture 90. In 1865 the aggregate total of $\$ 1,296,390$ in Federal income tax was paid by 2,336 Loulavilio Citizens. History of the Oh10 Falls Cities, 1,331 .

91. United Stetes Census, 1860. Manufacturing. p. 180. 92. Louisv1110 Journal, May 8, 1860.

93. Ib1d., septomber 8, 1860.

94. Ib1d., July 14, 186i. Loulsv111e Courier, Je. 8, 1860. 95. Ib1d., February 3,1860 . 
changed almost orernight. Most of the manufacturing Industries closed down and remained so for the duration 96

of the war. Prade with the South was limited and the teamsters "felt the pinch." The Louisville Journal began to bemoan the "hard times," and by lovember, 1860, dally appeals for help for the poor began to appear in 1ts columns. The Louisville Courfer lamented that although "Loulsville has a name and a place among the influential cities of our country, and we have wealth, elegance and refinement, still, in the many small streets, in the outskirts of the city, and even in our midst, there is suffering and want." In a later 1save the same newspaper reported that, "we understand that the hotel keepers...oring to the pressure of the times have reduced the number of their employees...they have also cut the wages of those they retain 11 ke 20 per cent. heretolore." A like problem was presented in the commercial establiahments. "Since the new year commenced we learn that hundreds of young men employed in stores and offices have been wholly thrown out of employment. The work of retrenchment having extended to all classes and every pursuit of $1110 . "$ The problem of unemployment became so acute that 96. Loulaville Journal, January 9, 1861. 97. Ib1d., Iovember 9, December 14, 1860. 98. Loulavilie Courier, January 8, 1861. 99. Ib1d., January 9, 1861. 100. IbIa., January 2, 1861. 
on the first day of the new year (1861) a publie meeting was held at the court house to consider the ateps that might be taken to reliere the situation. At this meeting an official comnittee was appointed to make a "survey of the aufering throughout the eity." As a result of the findings of the complttee sereral collocting depots were established in each of the wards "where those who have anything to give oan send articles of olothing, Puel and edibles." ${ }^{103}$ By Jenuary 30 (1861), the Journal was able to report that the depots had collected "potatoes, 135 bbls; flour, 76 bbl; beef, 3,310 1b8; pork, 8,500 1bs; and 12,000 bushels of coal, as well as a quanity of other edibles." These ward depots continued to operate through December, 1863, when the accounts of their monthly collections diseppear from the column of the Journal, but there is reason to believe that they continued to function until 1865 as occasional pleas are made for help for the poor. 105

Beside the ward depots other means were taken to reliere the suffering of the poor. Concerts were given by the various literary and musicel societies 101. Lou18v1110 Courlex, January 2, 1861. 102. IJId., Januery 4, 1861 . 103. Loular1110 Journal, January 3, 1861. 104. IbTa., January 30, 1861. 105. IbId, Ootober, 1864. pese1m. 
106

In the city, and the stock companies at the theatres 107

gave occasional benefits for the poor. The churches too, did their part with Sunday collections, churoh 108

suppers, and religlous plays. In one case an offering of $\$ 50.00$ was sent to the Loulerille poor "as a small offering from a few New Yorkerg."

There wag one reliof organization that functioned throughout the period of the war--the Volunteer's Rellef Committee. This "group of good ladies" was organized to care for the families of rolunteer soldiers who "were unable to take care of their loved 110

ones." At one time the group was taking care of more than 400 families in the oity.

There was very little rellef of unemployment in the winter and early opring of 1861; when J.M. Delph qualified as mayor on Apr11 29, 1861, he asked that "the expenditures on quarry work in improving the conditions of the streets, and in grading the whare, ete.. should be upon a scale that will gire employment to as many of the laboring poor as our financial 112 condition will permit us to employ." On May 11, 1861, 106. Loulavillo Journal, February, 1861. pas81m. 107. Ib1d., Apr 1T, 186I. pes81m. 108. IVTd.: December 22, 1860. 109. I01R., Januery 10, 1861. 110. Ib1d., November 9, 1861. 111. Ib1d., January 7, 1862. 112. IbId., Apr11 30, 1861. 
the "General Council passed an ordinanoe provlding for a loan of $\$ 10,000$. The object of the loan being to enable the city to employ a large force upon the 113

Btreots a a measure of rellef." By the middle of

May (1861) a force of more than 400 men were spreading 114

crushed rook upon the streets. But $\$ 10,000$ was not a very large sum of money, and it was estimated that if the fund were divided equally among the unemployed each leborer would receire but $65 \phi$. On May 30 an ordinance was passed by the General council direoting the mayor to submit to a rote of the citizens the ordinence "levying a tax of .20 on the dollar for the benefit of the poor." ${ }^{116}$ During the month of June (1861) the "unemployed mechanics of the city" twice petitioned the Counell for relief. 117

By the latter part of 1861 a certain degree of prosperity had returned to the city. Iouisville became the base of supply for the Union arm1es in the South, and her merchants were being awarded large contracts; "the prosperity naturally passed on down 118 to the teamsters and other laborers." The Cincinnati

113. Counc1l Records, Ho. 8, p. 89. Lou1ar1110 Journal, Apr11 30, 1861.

114. Lou1871ile Journai, May 13, 1861.

115. Ib1d. Hay 21,1861 .

116. Counoil Records, Mo. 8. p. 105. There is no eridence that the ordinance was ever aubmitted to a popular rote.

117. Ibia., pp. 122, 132.

118. Coulter, op. cit., p. 242. 
Commerolal reported thet, "the Immense distribution of army stores gives employment to a very large number of men, and contributes much toward the rellef of the poorer clasees of the people." ${ }^{119}$ It certainly gave more then enough employment to the teamsters. In the early days of Fobruary, 1863, they demanded higher wages, and 120

got them. Stookyards employees were also given work, as were semptresses and sewing machine operators. In November, 1861, the Loulav1l10 Journal reported that olothing contractors were employing large number of 121 women, and in 1863 the same newspaper ran an advertisment for "thirty semptresses and fifteen sewing machine 122 operators."

Because of the great influx of soldiers and army officers the hotels and boarding houses did a rushing business. Domestics were in great demand, and the store clerks and coffee house employees again found employment. But there was one group of laborers that found no relief until the end of the war--the mechanios. As has been previously noted, manufacturing practically ceased to exist during the war, and the greator number of meohanies were forced to rels upon rellef labor for a I1velihood.

119. Loul8ville Journal, Fobruary 14, 1863.

120. Ib1d., 10vember 26, 1861.

121. IV1d.: Trovember 23, 1861.

122. IbId., January 30, 1863. 
VI

The ultimate effects of the civil War upon the economic life and development of the City of Louisville is almost beyond belief. Prior to the war, Louisville was but another town in the rapidly growing West, whose commercial classes had hoped, by a strange formula of 75 per cent. business acumen and 25 per cent luck, not only eventually to control the trade to the south, but also to become the manufacturing metropolis of the West. Certainly "luck" hed played a large part in her early capture of the Southern trede. The two factors that gave her the commanding position in the decede 1850-1860 were; Pirst, the natural position of the "Fells of the ohio" which brought all river traffic to her door by foroing -re-shipment of practically all goods bound for the South as well as those bound for the North; and, second, the Loulsville and Nashville Railroad which was the only through railroad between the two sections. Thus by controlling the means of trensportation between the North and the South the city reaped the benefits of Northern wealth and Southern trade.

At the beginning of 1860, however, Cincinnat1 and Pittsburg hed not only out-stripped Louigville in 
industrial development, but were well on the way to supplant her as the mistresses of southern trade. The war came at fortuitous moment. Because of her border position, coupled with the fact that the olty became the base of supply for the Union armies, Louisville held the commanding trade position between the North and the South. The South needed Northern goods to carry on the war. Louisville merchants supplied them. The North demanded tobacco, cotton, and other Southern products. Louisville supplied them also. Thus it was thet even though industrial activity was virtually halted during the period of the war, the gain in trade far exceeded the 1088 of her manufacturing industries. 
Chart (A) nows the number of manufactures in Louisville in 1860 whose aggregate total

of products was more than one hundred thousand

doliars per yoar. Chart (B) ahows those manufactures whose aggregate total was more than one million doliars in 1865. Chart (B), however, is only an approximate estimate.

CHART 4

\begin{tabular}{|c|c|c|c|c|}
\hline Manufactures & $\begin{array}{l}\text { Num- } \\
\text { ber }\end{array}$ & $\begin{array}{l}\text { Capital } \\
\text { Investod }\end{array}$ & $\begin{array}{l}\text { Hands } \\
\text { Hmployed }\end{array}$ & $\begin{array}{l}\text { Annuel cost of } \\
\text { produots }\end{array}$ \\
\hline $\begin{array}{l}\text { Agrio. Implem, } \\
\text { Boots \& Shoes } \\
\text { Clothing } \\
\text { Flour \& Meal } \\
\text { Iron } \\
\text { Ieather } \\
\text { Provisions } \\
\text { Hernes8 } \\
\text { Sash, Doors } \\
\text { \& Blinds } \\
\text { Soap and } \\
\text { Candles } \\
\text { Tobaoco- } \\
\text { Menufactured } \\
\text { White Iead } \\
\text { Waggons and } \\
\text { Carts } \\
\text { Woolen coods }\end{array}$ & $\begin{array}{r}8 \\
14 \\
21 \\
15 \\
11 \\
10 \\
9 \\
24 \\
2 \\
8 \\
10 \\
1 \\
25 \\
3\end{array}$ & $\begin{array}{r}\$ 219,650 \\
49,950 \\
445,400 \\
174,800 \\
728,500 \\
121,000 \\
810,000 \\
52,600 \\
75,000 \\
131,250 \\
282,000 \\
52,000 \\
37,250 \\
54,000\end{array}$ & $\begin{array}{c}240 \\
152 \\
1276 \\
50 \\
455 \\
75 \\
1042 \\
110 \\
95 \\
96 \\
\\
557 \\
30 \\
96 \\
57\end{array}$ & $\begin{array}{r}\$ 387,100 \\
186,082 \\
683,960 \\
955,355 \\
828,600 \\
280,900 \\
3,460,575 \\
222,365 \\
126,500 \\
402,900 \\
628,000 \\
100,000 \\
122,967 \\
185,565\end{array}$ \\
\hline TOTAI & 161 & $3,233,000$ & 4,381 & $8,652,278$ \\
\hline
\end{tabular}

CHART B

\begin{tabular}{|c|c|c|c|c|}
\hline $\begin{array}{l}\text { Clothing } \\
\text { Iron } \\
\text { Pobaoco- } \\
\text { Manufactured } \\
\text { Provisions }\end{array}$ & $\begin{array}{r}56 \\
20 \\
100 \\
19\end{array}$ & $\begin{array}{c}700,000 \\
1,200,000 \\
500,000 \\
2,000,000\end{array}$ & $\begin{array}{l}2,000 \\
1,200 \\
1,500 \\
2,500\end{array}$ & $\begin{array}{l}1,100,000 \\
1,500,000 \\
1,000,000 \\
5,500,000\end{array}$ \\
\hline TOTAI & 295 & $4,400,000$ & 7,200 & $9,100,000$ \\
\hline
\end{tabular}


SOCIAL AID CULTURAL DEVELOPMEITT

Generally speaking, there were three fairly well defined sooial classes in the city of Loulsville prior to the Civil Wer. There was, firat, the "upper class" composed of the moneyed people, and, to a certain extent, those who could command entrance to "soolety" because of their"blood lines." Second, there was a midde olase, composed of small manufaoturers, small business men, and skilled mechanios; and lastly, there was the lower olass, composed of unskilled mechenics and laborers. The lower class was by far the most numerous. Although there was a certain amount of intermingling between the upper and midale classes there was as wide a gulf between the upper and lower groups as there is at the present time--and thet in apite of the "equality of democracy" of the age. The residential districts were widely separated; the ohildren of the wealthy were - sent to schools in Boston and Philadelphia rather than 1 to the public schools, and there was little or no possibility of inter-marriage; and, to make the gulf

1. Reminiscences of S.A. Rodman. Ioc. cit., p. 20. 
more pronounced, society had its own saloons and gambling houses at which the mechanics and laborers were not welcomed.

But the elements of war recognizes no social barrlers or differences. On the battle field the banker fights at the side of the laborer, the Jew beside the contile, the strong beside the weak, and "they are all brothers fighting for a common cause." Much the same breakdown of the socisl distinctions occurs away from the bettle field in time of war. The rich man drinks beside the poor man, the society belle nods daintily to the young teamster, and the soldier becomes an exalted being, one to admire, love, and, above all, to bld welcome to those social circles where heretofore he has not only been unwelcome, but forbidden. Louiswas like any other city in this respect. Soldiers were everywhere, crowing the theatres and hotels, some gallantly escorting demure, crinolined belles, others quarreling drunkenly in the saloons; but they were soldiers, and es such, rich or poor, blue-blood or illegitimate, they were welcomed in some of the best homes, on the streets, at the quadrilles, with "smiles and cheers."

Curiously' enough, however, even patriotism begins 2. Louisville Herald Post, Magazine Section, April $18,1926$. 
to wane after a few years. Where once the populace "waved at the passing defenders of their homeg" there comes a spirit of arrogance, intolerance, and selfishnos8. Men begin to wonder whether the breakdown of the sooial institutions is worth the "false loyalty of protection." By 1863 Louisville was thoroughly disgusted with the army and the men within its ranks. The oitizens no longer smiled with indulgence at drunkenness, or et the racing of horses through the main streets. Rather the Journal, as spokesman for the community at large, hurled bombastic thrests at those uncir$111 z e d$ "men who call themselves soldiera." Progitution was setting a bad example for the "locel men and women," and accusations were made thet the moral and social ingtitutiong were being destroyed by the continued occupation of the city by the army. More than one inhabitant expressed the wish that he might never again see a soldier. Undoubtedy the military ald play havoc with the social institutions, and the citizenry might here been fustified in their attitude of intolerance which was to continue until the end of the war. 3. Loulavilie Journal, March, 1863. passim. 4. Ib1d., Jan. 24, 1863. 5. Ib1a., Jan, $27,1863$. 6. IbId., Jan. 21, 1863. 7. IbId., Feb. 3, 1863. 8. Ib1a., April 6, 1863. 
The churohes were the firgt of Loulsville's goelal and moral institutions to feel the effects of the confliot when dissension arose, both between the varlous denominations and within the churches themselves, as 9 to the moral right and wrong of slavery. Even before the actual outbreak of hostilities the varlous congregations oplit into bitter camps, and many preacher gare up the Bible for the pamphlet of politios. The Sunday sermon in many ohurches did not deal so much with the Gospel as with the "right or wrong of slavery and union or s0008sion." The Loulsvilie Journal saw fit to print a ourrent joke: 'a rallroad conductor heving been asked how politios were going on replied-"I haven't been to churoh for four Sundays, and I con't know." " But in a more serlous rein it lamented the fact that, "the unfortunate introduction of pol1tios into the affairs and organizations of our religious sooleties has been the cause of much ev11." ${ }^{11}$ so heated became the controveray that scarcely weok went by that the local newapapers did not print a sermon either 12 upholding or condemning the slave traffic. It has been 9. Blographlogl Enojeloped1a of Kontucky, p. 15 . 10. Louiav1lle Journal, January 8, 1861. 11. Ib1d.

12. For instance, Louisville Journal, January 15, 18,1861. 
aptly stated that, "the opfeot of slavery and the Civil War on the churoh was stronger than the effect 13

of the church on them."

Interesting logal questions regarding churoh gorernment and authority were dereloped, especially the relation of ohurch and state in the separation of the Methodist and Preabyterian churches. Probably the greatest dissension arose within the Presbyterian Church where "the politioal disturbances proved a baneful source of disturbance." 15 The sect had always recognized its duty to mold publio sentiment on moral questions, but now certain groups within the Church went even further and brought up the question of the "allegiance of the Christion oftizen to the Federal Government" when a moral duty was at stake. The resulting "Church War" was not only carriod on from the pulpit and from within the "Governing Council of the Churoh," but reached its height in bitterness in the columns of the looal newspapers of 1861. In that year the Rev. Thomas H. Hoyt published a strong sermon in the Delly Courier urging secession; 168 than two weeks later, a fellow olergyman, the Rev.

13. Wickenden, H.E., H18tory of the Churches of Loulsv1110 With Speoial Rererence to Slavery. (M.A. Thesis, Univergity of Loularille Intro. pp. $2-3$.

14. Ibid., p. 3 .

15. Johnston, 2, 169.

16. Louibv1lie Da1ly Courier, January 5, 1861. 
Charles Parsons published an adress refuting Hoyt's arguments and urging that Kentucky remain within the 17

Un1on. In the same jear, after the courler-- the only Loulsville newspaper thet held forth open oolumns to secessionists--had cessed publioation, Dr. Strart Robinson, the pastor of the Second Presbyterian Church, began the publication of the "True Presbyterian." This religious publication was twice suppressed by the milltary authorities because of its strong anti19

union sentiments. The ultimate effect of this internal disgension was the division of the churoh into a "Northern and Southern branoh."

Ilkewise, "gplits and breaks" took place in the Protestant Ipisoopal Churoh, the Methodist Churoh, and in practically every other denomination in the o1ty. Only the Cathollo Churoh remained to show anited front to the Union. Although the Catholio Churoh deplored "human bondage" and would have been exceedingly happy to see it disappear from the face of the earth, the official "Church Government" took no part in the controversy and sought to stand upon neutral ground. Doubtless, however, many members of that

17. Lou18r11le Courier, January 18, 1861.

18. Blographica Hnoyolopaedia of Kentuoky, p. 15. 19. In July 1862 and Norember, 1864 . 20. Dr. Ford, Baptist preacher, left Louisville in 1861 and went south to the Confederacy. He was a member from Kentuoky at the Iirst Confederate Congress. Wiokenden, op. oit., p. 17. 
faith were not wholly in agreement with the Churoh polioy. In spite of the dissension within the local ohurohes the moral forces within the community managed to do a great deal of humenitarian work during the war. In 1861 Bishop John Spalding (Cathol10) entered into an agreement with General Robert Anderson in whioh it was agreed that, "The sisters of Charity will nurse the wounded under the direction of the army surgeons without any intermediate authority whatsoever...every thing necessary for the lodging and nursing of the rounded and sick will be oupplied to them without putting them to any expense, they will give their services gratultously...and...so far as oircumstances will allow, they shall have every faculty for attending to their religlous and derotional exercises." Under the terms of the agreement the sisters of Cherity established and maintained two military hospitals during the remeinder of the war--one at Mar. Munn's plow factory, at Ninth and Broadway," and the other at the "Avery plow factory."

The individual congregetions of the other denominations, assisted by the Young Mens Christian Association, likewise aided the 111 and wounded. In 21. Johnston, $2,121$. 22. Ib1d., 2, 278 . 
September, 1862, when the military authorities confiscated the public ward sohools, a number of churches came to the rescue of the Board of Education by offerIng their Sunday-school rooms as temporary school 23 rooms.

Due to the gain in population, plus the split of many congregations into individual units, the number of churches in Loulsville had increased tremendously by the ond of the war. In 1860 there were 57 churches with an average number of 1193 people per church. In 1870 there were 83 churches with an average number of 1214 people per church. The Episcopal Church made the greatest gain in the number of congregations-from 3 in 1860 to 13 in 1870. The number of catholic churches incressed from 10 to 15 , and the Presbyterian churches from 6 to 13 during the same perlod. There were like increases in the other denominations.

The following chart shows the number of churches in Louisville from 1850 to 1870, with the average number of people per church. The negro churches are also included, although not under separate listing.

23. Louisville Journal, October 22, 1862.

24. Wickenden, op. o1t., Chart contrined in bibliography. 
1

CHART SHOWING GROWTH OF CHURCHES

\begin{tabular}{|c|c|c|c|}
\hline & 1850 & 1860 & 1870 \\
\hline $\begin{array}{l}\text { Presbyterian } \\
\text { Episcopal } \\
\text { Methodist } \\
\text { (North) } \\
\text { Methodist } \\
\text { (South) } \\
\text { Catholic } \\
\text { Evangelical } \\
\text { Reform } \\
\text { Baptiat } \\
\text { Christian } \\
\text { Iutheran } \\
\text { New Jerusalem } \\
\text { Jewish } \\
\text { Oniverselist } \\
\text { Unitarian }\end{array}$ & $\begin{array}{r}5 \\
3 \\
1 \\
12 \\
3 \\
3 \\
0 \\
6 \\
1 \\
1 \\
1 \\
1 \\
1 \\
1\end{array}$ & $\begin{array}{r}8 \\
5 \\
3 \\
12 \\
10 \\
4 \\
1 \\
8 \\
2 \\
0 \\
1 \\
2 \\
1 \\
1\end{array}$ & $\begin{array}{r}14 \\
12 \\
4 \\
18 \\
15 \\
4 \\
1 \\
9 \\
4 \\
1 \\
1 \\
2 \\
0 \\
1\end{array}$ \\
\hline TOTAI & 38 & 57 & 83 \\
\hline $\begin{array}{c}\text { Population of } \\
\text { city }\end{array}$ & 43194 & 68033 & 100754 \\
\hline $\begin{array}{l}\text { Average num- } \\
\text { ber of people } \\
\text { ahwreh. }\end{array}$ & 1136 & 1193 & 1214 \\
\hline
\end{tabular}

This chart (with fer minor changes) is taken from Wickenden, op. cit., Bibliography. 
The number and variety of amusements presented in Loulaville during the perlod of the war was truly ameing. Among the most popular were the visiting museums, which at one time or another presented a diverting combination of the educational with the faroical and morbid. As the war dragged on the clairvoyants, astrologists, phrenologists, ventriloquists, mesmerists, and spiritualists held the public attention in turn. During the summer months there were the inevitable circuses whose menageries, performing ponies, trained lions, and siamese twins were highly attractive to the old as well as the young. Picnics too, were ever popular. Publisher Prentice, who seems to have had an aversion to these social affairs, wrote: "These oheap, rational, but rather fatiguing entertainments are now in full blest at all the groves and gardens in the neighborhood of the city. The ultimate objects of the festive gatherings are varlous but mostly religious, charitable, or patriotic. There is a real moral

25. For ingtence, Louisville Journal, July 3, 1863; 1bid., Aug. 12, 1864. 
heroism in the way that some people attend picnics. They rise eerly. They take their whole house-hold flock with them. They carry enormous baskets. They wedge themselves into oars, or pack themselves into stages three deep, or stand in the burning sun on the decks of steamboats. They then arrive within a mile or so of the parking ground. The rest of the distence they walk. The day is one of heat, fatigue, and thirst. During the afternoon a shower sets 1n. After waiting three hours under dripping trees for the westher to clear up, it does not clear up. The crowd sets out for home. Arriving there wet and tired, but ready for another plento 26

the next day."

IV

Even though more than 5,000 Louigville men enlisted in the Union and Confederate armies during 27

the perlod of the war, the belles of Louigville did

26. Loulsville Journal, Julg 2, 1863.

27. There are no acurate figures on the actual enlistments from Loulavilie. On July 6, 1863, the Journal estimated that 5,000 men had left the city. But for the entire perlod of the war it seems safe to estimate the enlistments as not under 8,000 . 
not suffer from lack of partners at the dance. The influx of soldiers and partners more than made up the deflcit. Indeed, so numerous becamt the "Grand Military and Civic Balls" as well as the private parties and dances, that the Journal felt called upon to report that, "balls are given for any benefit, at any time, for the orphens, for the rellef of the poor, and for pleasure." 28 scarcely a night went by but that a quadrille was given at one of the local halls. During the winter of 1863, "Houpt's Silver Cornet 29 Band," which had "the best prompter for bells in the c1ty," was forced to announce, in the columns of the local newspapers, that due to the heavy demand upon their services they would be unable to accept engagements for more than a month.

But if the citizens of Louisville pertook of many amusements thet were innocent and populer, there

28. Louigville Journal, July 2, 1863.

29. There were dozen or more lesser dance bands in the city, but in contract to the decade before the war, when there were numerous advertisements asking for engagements appearing the the newspapers, such advertisements after 1860 were so unusual as to attract attention.

30. Loulsv1lle Journal, Dec. 8, 1863. 
were other forms of amusement just as popular but not so innocent. Gambling, always common in Loulsville, "burned into a fever that seemed all coneuming during the civil War. There was just enough gambling houses, with enough patrons and free money to keep them open day and night." The poor as well as the rich played at the green baize tables. More than one professional gembler reaped a fortune from the army officers and army contractors who over-ran the city. The Louisville Journel reported one incident of an army contractor losing more than a quarter of a million dollars at one "session." These "gilded temples" made no effort at concerlment and openly occupied whole blocks in the contral part of the city. "All the north side of Jefferson street from Fourth to Fifth, all the east side of Fifth from Jefferson to Market, and practically all the south side of Market from 33

Fifth to Fourth "was deroted almost exclusively to keno, roulette, faro, and other games of chance. Racing too, had its day. During 1860 and 1861 the Woodlawn Race Course--situated six miles east of 31. Courier Journel, Sunday Magezine Section, Feb. 8 ,
32. Louisville Journel, oct. 17,1863 ,
33. $\frac{\text { Courier Journal, Sundey Megezine Section, Feb. } 8 \text {, }}{\text { Ig20. }}$ 
the clty--held both spring and fall moetings, offer34

ing purses from "200,00 to $\$ 500.00$. These purses were uncommonly large for the period, and many horses from the surrounding states were brought to Loulsville to compete for the prizes. The races were run according to the rules of the course, and all jockeys-colored boys--were required to wear the distinctive garb of their calling. At the "Spring Meeting" of 1861 the Iouisville Journal reported that the crowd was large, "with both sexes present, and the betting was heavy." After 1862, however, the meetings were suspended and no regulation meets were held until after the end of the war. But even though no formal meetings were held an occasionel day of racing was offered to the gambling publio during the summers of 36 1863 end 1864 .

VI

The citizens of Louisvilie seem to have tried to drown their sorrow in hard liquor during the period of the Civil Wer. Rich and poor alike partook of the 34. Loulsville Journa1, Mey, 1860. peesim. 35. IbId., May 20, 1861 .

36. For Instance, Louisville Journal, Oct. 22, 1862; Ibid., July $7,1863$. 
heady beverage, and it was not uncommon for wines and brandy to be served in the homes of the beat citizens. The pages of the local newspapers contained column after column of advertisements of I1quor for sale--not by pints and quarts, but by gallons and barrels. For those who welcomed company while they drank there were approximately 400 Iicensed "Coffee Houses" within the limits of the 37

oity in 1860. It has been stated that, "the growth of this industry exceeded in proportion the growth of any other activity, and it is possible that the thirst of the population was such as to demand a 38

large supply." Certainly the number of saloong had increased by more than one-third during the period of the war. In 1864 the city fathers issued more than 600 licenses for seloons and coffee houges. Differing radically from a later day, the proprietors of the s8loons merited no stigme because of their calling. On the contrary, the Louisville Journal constantly extolled the virtues of these dispensers of hard liquor. "They (proprietora) have merited the esteem of the community, for their 37. This number was arrived thy counting the number of licenses lasued in the Journal of the Common Counc11, 1860. No. 7 .

38. Loulsvilie Herald Post, Mag. Section, Ap. 18, 126. 39. Journal of Common Counc11, 1864. No. 9 . 
great politeness and attention to visitors, and for the excellent quality of their 11quors. We hesitate not to recommena our saloons to all amsteurs." Perhaps this praise was forth-coming as a result of the many gifts of wine and liquor thet were given the editor by these selfsame proprietors. Certainly Prentice drank his 11quor with the best of them. A contemporary wrote, "many times the narrator has seen Mr. Prentice walking, and gifted as he was, yot at times his steps were not steady and probably there was a reason, as it is sald that $\mathrm{Mr}$. Prentice indulgod a little too freely of ardent apirits."

From Prentice' editorial it would seem that drinking was a professional calling; from the small number of arrests, drunkenness was either exceptlonally common, or the drinkers could carry their liquor, as police records prove that Louisville was on orderly c1ty. It was uncommon for the police to make more than three arrests for drunkenness in any one day. The soldiers that over-ran the city seem to have caused the most trouble. The Louisville Journal reported that soldiers and officers crowded the 40. Louisville Journal, Jan. 8, 1861. 41. Sumners, Ioc. c1t., p. 8 . 
saloons night and day, and remained in a constant state of drunkenness. "The nuisanoe is as offensive to civilians as it is disgraceful to the army... and... they race horges up and down our mein streets without regard to 11 fe or $11 \mathrm{mb} . "$ "The military authorities sought to remedy the situation by forbidding the saloons to sell liquor to the soldiers, and when the orders were disregarded the s8loons were 45 closed for a short period of time. On the whole, however, Ilquor was sold to any and 211 who had the price of a arink.

VII

The dress of any period serves as a point of interest to the contemporery historian, but the arese of the sixties is particularly interesting because of the grotesque effect produced on the outer aspects of social life by the hoop-skirt. In 1860, the "Feshion set" of the Fast, following the example of the Empress Eugenie, set its seal of approval on this 42. Loulsville Journal, Dec. 2,1862 .

43. Ib1d., Jan. 29, 1863. 44. Ib1d., Jan. 24, 1863. 45. Ib1d., Feb. 6, 1862; March 9, 1863. 
"most obnoxious form of feminine costume." But it was not until the latter part of 1861 thet the dress was worn by all classes of women in Louisville. A 46 popular song ran thus:

"Now crinoline is all the rage with ladies of whatever age,

A petticoat made like a cage--Oh, what a ridiculous feshion!

ITs formed of hoops and bars of steel, or tubes of air which lighter feel,

And worn by girls to be genteel, or if they've flgures to conceal.

It makes the dresses stretch far out a dozen yards or so about,

And pleases both the thin and stout--Oh, what a ridiculous feshion."

So exaggerated became the fashion that it became both the bane and laughing-gtock of humanity. Scarcely a week went by but that the daily newspapers gave an account of what wag called a "crinoline accident," cases, that is to say, in which a woman suffered an accident as a result of her distended drapery. Accldents 8 s the result of fire were the most common, the Louigville Journal reporting cases in which a woman was "severely burned" or burned to death because of some flame of fire or candle catching her dress at an unexpected moment. The noted historian, 46. Moclellan, Elizabeth, Historicel Dress in Americe, Phila: G.W. Jacobs \& Co., 1910. p. 263.

47. For instance, Louisville Journal, Merch 4, 13, 1862; Feb. 7, Aug. 9, 1863. 
MeCarthy, in his "Portraits of the Sixties," says: "There were sacrifices made to the prevailing fashion which would have done the sufferers immortal honour if they had been made for the sake of bearing some religious or politicel emblem condemned by ruling and despotic authorities."

The inconvenience of the hoop-skirt was felt by the male population as well as by the "ladies who sported the obnoxious construction." The Louisville Journal, tiring of poking fun at the "steel cage which protects the lower extremities of our ladies," rose in wrath to bitterly assault those women who 50 wore the "contraption in public places." The Ioulsville Democret added its bit to the general conPlagration by declaring that the hoop-skirt should be forbidden from the public omnibusses and treins. The theatre managers also had their troubles with the cage. During the season of 1862-1863 practically all of the theatricel advertisements contained a Iine to the effect that regular prices would be charged for extra geats used by the women. But the 48. Cited in Meclellan, pp. 264-5. 49. Louisville Journal, February, 1862. pass1m. 50. IbId., March 5, 1863. 51. Louisv1lie Democrat, Aug. 7, 1863. 52. Louigvilie Journgl, Fob. 6, 1863. 
hoop-skirt served a good purpose to those women who sympathized with the Confederate cause--many a pistol, and bits of contraband, were carried through the Union lines beneath the "flowering skirts of adventurous women."

By the end of the war the hoop-skirt wes beginning to decline, and the change for the better was 54 joyously recorded by "Punch."

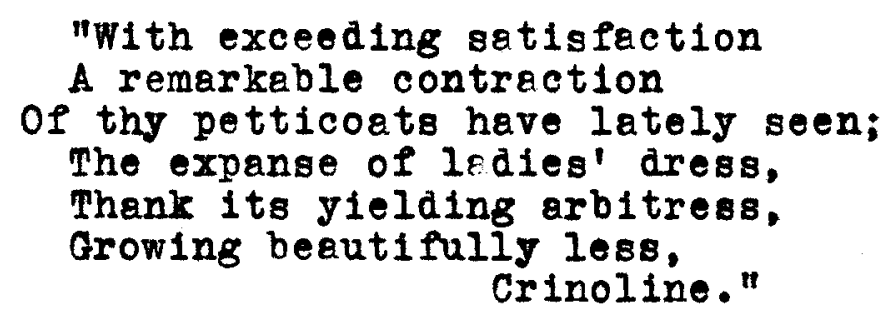

With the Inaugeration of the hoop-skirt came the revival of the "becoming fashion of wearing black velvet around the throat." In the evening the more feshionable ladies wore a gold locket or a jewel pendant, while gold chains and rows of gold beads were elso very popular.

The prevalent style of colffure, popularly known as the "waterfall," was almost as uncomfortable and outrageous as the hoop-skirt. "A frame of horse halr was attached to the head by an elastic, and the 53. Louisville Journal, May 20, 1861. 54.cited in MCCleIIan, p. 271. 
back hair brushed smoothly over it, the onds caught up underneath. A net wos usually worn over this 'chignon' to keep the hair in place. Often the whole structure was made of false hair and fastenod on with hair ping." To make the effect more ludicrous, this "artifical crown of glory" was topped by rather small bonnet, often "made of emerald green velvet with a brim of white bengaline, a full trimming next the face of blond lace, green velvet and white roses, and two sets of strings, one of white ribbon and the other of green velvet," or, perhaps, a "large water lily with buds and leaves" might be substituted for the 56 roses.

The color and cut of men's wear was as sober and conservative as that of the women was gaudy and extreme. The small "Cartes deVisites" of the period show long black shiny broad-cloth frock coats, rather loose pantaloons and loose careless neckties. The hoir was worn rether short than long and beards and whiskers and moustaches were all popular. Jewelry was much admired and worn, not so much for the quality as for the size of the stone. 55. Moclelian, op. c1t., pp. 2T2 1 . 56. Ib1a., pp: 273-4. 


\section{VIII}

Higher culture seems to have received comparatively little attention during the period of the war. There is no mention in the dally newspapers of exhibitions of painting or sculpturing, and library facilitios were almost nil. The Kentucky Mechanios Institute, whose one thousand members were composed 57 mainly of ladies and minors, had a library of five thousand five hundred volumes, but with this exception the reading public was forced to depend upon 58

the bookstoros and newspapers.

There were any number of debating, literary, and scientific societies in the city. In 1860 "The Society for the Advancement of the Natural Sclences of Louisville, Kentucky, "was created a body politic and corporate by the Generel Assembly of Kentucky. Although the soclety had the "power to acquire real and personal property by gift, purchese or devise, or bequest, not to exceed in value, exclusively of any library, scientific apparatus, or collections of any

57. Tanner's Ioulaville Directory, 1861, p. 337. The Institute was orgenized in 1852.

58. Undoubtedly there were a number of private librarles in the city, and most of the general stores carried a limited number of books. 
kind for scientific purposes the sum of 125,000 , there is no evidence that the society functioned during the period of the war, or that it had any immediate cultural effect upon the city.

The Frenklin, Henry Clay, and Webster deboting 60

socletios held glmost weekly meetings at the Mesonic

Theatre to which the public was invited, and the varlous literary societies did their pert toward the uplift of the citizenry. In 1865 the "Louisville Mutual Literary Beneftt Society" was incor61 porated, 8.s we.s the "Harmony Soclety of Louisv1lie," the purpose of the latter being "to establ1sh a librery and reading room for its members, a hell for literary alscussion, and an enlightened 62

social intercourse among 1 ts members.

IX

The theetre, with its "genteel dramatic art," contrary to generel expectations, seems to have 59. Acts of the General Assembly of the Commonwealth of Kentucky, 1859-60, Vol. II, Chep. 481, p. 178. He1tz, Flora, Comprehensive surbey of Cultural Movements in Ioulsvilie, (M.A. Thesis, University of Louisvil10, 1937) pp. 45-6.

60. Tanner's Louisville Directory, 1861, p. 337.

61. Heitz, op. cit., pp. 48-9.

62. Ib1d., $\overline{p p} . \overline{49-50}$. 
enjoyed, during the entire period of the war, an increase both in the number and kind of entertainment offered, as well as increased patronage by both 63

the higher and lower orders. The season was also lengthened unt1l, in 1862, the Louisville theatre was offering entertainment throughout the summer months, while the lesser thestres and halls were open from the first of september to the latter pert of 64 June, or the first of July. Besides the legitimate theatres there were numerous halls offering occasionel Bell Ringers, Acrobets, and other lesser entourages, but it remained to Mozart Hall, the Masonic Hall, and the Iouisville Theatre to supply "continuous and active attractions to Louisville petrons..." Mozart Hall, catering to the "hol poltot," had long been a place for amateur theatricals, for concerts, for opera, for ministrel troops, and for other exhibitions requiring the use of a fair sized audi66 torium. In 1858 it had been ifted up as a regular theatre with an "enlarged stage and stationary cheirs," 63. Dietz, Mary Marthe, History of the Theatre in Ioulsville, (M.A. Thesis, University of LouisजIlle, 192i) p. 78 .

64. Louisville Journel, July, 1862. passim. 65. Ib1a., oct. 8, 1863.

66. Dietz, op. cit., p. 73. 
but continued as a variety and intermedite legitimate theatre until 1863, when it was opened as "Woods Theatre," offering at its formal opening, "The 67 Seven Sisters--with orchestral renditions." During the same year the now theatre offered matinees for the first time in the history of the city, and the other major theatres were soon forced to follow 68 suit.

The Mesonic Theatre could herdly have been called a thertre. It was simply a large hall where all sorts of engagements were played. It offered a place for performances of magicians, opera troops, Swiss bell ringers, drametic readers, and an occastonal curosity exhibit. Tom Thumb and his company gave a series of performenoes there in 1862, and 69

returned in 1864, to the great delight of the ohildren of the city; in 1862 Artemus Ward presented his "Sixty Minutes in Anerica."

But the real theatre and playhouse that engaged the attention of Louisville drama lovers was the 71 Loulaville Theatre. On its stage appeared most of 67. Dietz, op. c1t., p. 73. 68. Louisvillo Journal, Oct. 1863. passim. 69. Ibid., Jan. 26, 1864 . 70. IbIa., Deo. 24, 1862 . 71. The heatre was destroyed by fire in the winter of 1866. Johnston, 2,330 . 
the famous actors and actresses of the day. Frank Mayo, Edward Lewrence, Helene Madjeska, and Laura Keene, to mention but a few of the more important, bowed to the ploudits of the crowd. In 1862, John W1lkes Booth, the "almost perfect ham," played to crowded houses, and two and a half years thereafter achleved a terrible celebrity by the murder of 74

President Iincoln and his own tragie death.

The play-going Loulgville of the sixties gave appreciation to several varieties of appeal, including the very worse as well as the very best. It was during the dramatic season of 1860-1861 that the thertres presented, and the public accepted, that curious form of entertainment known as the "Spectacle." The vogue for this type of stage production--it was but a vogue--was not to enjoy a very long life. The main theme of the production--it would be pure charity to call the "Spectecle" a play--wes for the players, gorgeously costumed, to parade and pose before elaborately peinted backdrops that represented some important event in history, or, perhaps, to pose 72. Dietz, op. c1t.,p. 6\%.

73. "John WIIkeg Booth on Tour," Alva Johnson, SaturEvening Post, Feb. 19, 1938. Vol. 210. No. 34.

74. History of the Ohio Falls Cities, 1, 327.

75. The "Spectacles" onfoyed a revival in the 1920 's on the burlesque tager of the country. 
76

among the "papier-mache" loebergs of the Artic Circle. But after the season of 1862 the galleries resounded to such sentimental and "blood and thunder" plays as "Lovers Sacrifice," "The Femele Gembler," "Still Waters Run Deep," "The Corsican Brothers," and that play of plays, "The Hidden Hand."

The price of admission was practioally the same in all the theatres during the perlod. The "Dress cirole and Parquette" being $75 d$, the second tier and frmily circle $35 \%$, and the boxes $\$ 5.00$. For the colored people and the mechanics there were gallery seats at $15 \%$, as well as a small section of boxes for $35 \%$. But with the return of a certain degree of prosperity in the summer of 1862 the Eouisville Theatre and Mesonic Theatre odvanced their gellery prices to 25\%; with a few minor exceptions that price 77 remeined fixed through 1865 . It was not uncommon for a management to advertige thet if a lady wished to occupy more than one seat then she would have to pey for the extra seats used. That was but one of the prices a belle had to pay for hoop-skirts and 78 ruffles.

76. During the week of Feb. 7, 1861, the Louisville theatre was presenting, " $A$ Beautiful panorame of the Artio Reglong." Journal, Feb. 7, 1861.

77. Loulsville Journal, July 1, 1862. 78. Ib1d.,Feb. 6, 1863. Dietz, op. cit., p. 75. 
It would be impossible here to enumers te and follow in deteil the numerous harmonic and musical societies that existed in Louisville during the Civil War. Due to the large German population music had corved on important niche in the elmost blank wall of Louigville culture. The Musical Fund Society, organized by Professor E.W. Gunter, seems to have been the most important of the orchestral orgenizations. It was composed of the finest talent of the city, and at a concert given in 1861 it was reported that "a large and feshionable crowd attended." Unfortunately, the orgenization was disbended early in the "war, and no concerts were given after 1862 .

Professor Gunter also organized the Mozart Soclety, whose objective was to give secred voice concerts. This orgenization functioned throughout the period, and at the end of the war the society was called together for its last concert. This "Pegce Festival" ended as it has begun, with the singing of the "Crea82 tion." There were many other singing societies, the Concordia singing society and the Lieder-Kranz being 79. Johnston, 2, 88 . 80. Ibid. 81. Edward's City Directory, 1865-66. p. 172. 82. Johnston, $2,86-7$. 
the larger and more important. The latter, founded by the German male population, sponsored the first 83

"National Saengerfest" held in the West. There were also numerous small private groups, such as the Beethoven Piano Club, who met at private homes to play for their own amusement. This club, composed of twelve young ladies--aided by one male member--achleved quite a reputation in local musical 84 circles.

\section{$\mathrm{XI}$}

Louisville's literary world wes no different from that of other cities during the period. Romanticism, didacticism, and sentimentality were conspicuous factors in the prose and poetry of the age. But with the exception of a few minor writers Louisville's contribution to literature both before and during the war was negligible. Thonas H. Shreve-one of Iouisville's own sons--whose work was described by a fellow poet as being "as joyous in his verse as the lark soering in the early morn," was 83. Johnston, $2,86-7$. Journal, July $24,1866$. 84. Ibid., 2, 87 . 85. Ibid., 2,72 . 
one of the more important poets whose work appeared in many of the megazines and newspepers of the day. William David Gallagher and W.S. Fosdick were both widely read and discussed, but it remained for Fortunatus Cosby to capture the imagination of the ladies with such bits of verse as:

"I will snetch from the sunset its roses, The bloom on your lips to display;

From the woodbine the sweets it discloses, The sweets they concerl to display. I will rob the gazelle of its splendor That lives in her lenguishing glence, But to show that your own is more tender, And soft as the dream of romence."

Not all of the verse of the day, however, was as romantic and sentimental. Scarcely a day went by but thet the columns of the local newspapers contained a dramatic or tragic poem dealing with the Civil War. The two writers who most erequently apoeared in the Iouigville Journal were Flla Caldwell Morse, whom Prentice labeled "an old favorite," and S.C. Mercer, whose dramatic poem, "With Thy shield, Or Upon It," will serve to illustrate the type of verse that received the plaudits of the city:

"Sound the trumpet, Sound! The die is cast, The Rubicon of fate is passed, The loyal and the rebel hosts,

86. Loulsville Journal, Jहn. 17, 1861. 87. Ib1a., Jan. 22, I862. 
Kentucky, throng thy leagured coasts;

And on the issue of the strife, Hang pesce, and liberty and life; All that the storied past endears, And all the hopes of coming years; The startled world looks on the field-Thou canst not fly--thou der'st not yield-Then strike! And make thy foemen feel Thy triply-consecrated steel, And with or on thy shining shield, Return Kentucky, from the field."

The numerous literary socleties found it impossible to support any kind of a literary magazine and the intelligent reading public depended upon the columns of the many newspapers published in Louis88 ville for an occasional short story or essay, or upon such national magazines as Putman's Monthly Magazine, Herper's Monthly, and Clark's Knickerbocker, from any of whose pages might be read such short stories as "Annie at the Corner," or, "The Boy at the Iighthouse." In the same issue the young ladies might blush on reading the "Scandals of Paris," while the young blades mulled over such gems of wisdom as, "If you want to wreck a thorough vengeance on a woman, you must first make her love you." For the more serious minded of whom an English 88. In 1861 there fifteen weekly and monthly newspapers published in Louisvilio.

89. Putman's Monthly Megazine, 1863. Vol. CIII, No. XIIII.

90. Ibid.

91. From "Tom Mallory's Revenge," Herper's Monthly, Aug. 1865, Vol. XXI. No. CLXXXIII. 
visitor fudged "are as familiar with English litervisitor judged "ine as ature as our own respectable journalists," the bookstores furnished such "best sellers" as, "The Advontures of Pravelers in Africa," "Faraday's Lectures on the Physical Forces," "Thoughts on the Future Civil Policy of America," "Over the Cliffs," or, perhaps, "Abel Drake's Wife," a novel by John Sanders, of whom Prentice described as being "a fine juage of human character and neture, and his novels leave artesian wells in the heert, from which tears bubble to the eyes."

It is exceedingly doubtful, however, whether the greater mass of people read many of the magazines or books mentioned above, but there was one publication that was devoured by the educated as well as by the "hol poll1"--the Iouigville Journal. Edited by George D. Prentice, probably the most powerful of all the ante-bellum editors in the southern states, and about whom Henry Watterson once wrote, "From 1830 to 1861 the influence of Prentice wes perhaps greater than any political writer who ever lived," the Journal became well known on both sides of the Atlantic. It

92. Mass10, op. c1t., p. 286. 93. Iouisvilie Journal, July $3,1862$. 
is probable that Prentice prevented the secession of Kentucky, and although he was no firm believer in Iincoln, the Journel, during the entire period of the war, "was a staunch supporter of the Union." In addition to being the foremost Whig editor, Prentice was one of the first of the newspaper paragraphers, "his pungent paragraphs winning for him quite a reputation as a humorist, while he also achieved more than locel fame as a poet."

$\mathrm{XII}$

It would hardy be possible to exaggerate the social and culturel effects of the end of the period of the Civil War, or the colorful romance of that period while it lasted. Vivid pictures of the social life of the period form, as it is fitting they should, the background of some of the best Americen novels.

The early years saw the breakdown of many of the rigid social distinctions. All men, high and low, banded together ageinst the unwieldy, although plcturesque hoop-skirt. There were war marriages 94. Dabney, Virginfus, Ifberalism in the old south, Chapel Hill, Univergity of North Carolina Press, 1932. p. 136. 
between the upper and lower classes, and rich and poor met upon the same plane. But before the strife had been brought to a close these same social distinctions were drawn the tighter, and the gulf between the clagses had grown the wider. Too, families were split, friends became enemies, and the ministers of God were divided. The war animosities created a breach that took generations in the healing, or, as in the case of the churches, had not been healed seventy years after.

Although the cultural phases of life remained comparatively static, the frivolous moments of the population seem to have increased in proportion to the tragedies of war. The people tried to lull themselves into forgetfulness by the ir very manner of living. The steady gait of parties and dances, the theatre and other entertginments, as well as the urge to drink and gamble, became faster os the war lengthened from months into years. All sense of perspective was lost. The tradition of placid living was lost in the strains of martial music. Strident laughter became the dominant note in all conversation. The "repid pace" was carrled over into the serenties, and except for a brief respite in the eighties, reached its crescendo in the nineties. Louisville seemed destined never to forget the "War between the states." 


\section{THE AFTERIAATH}

Apponattox brought rejoicing to all Louisville even though "it was tinged in many a heart with a feeling of sadness for a ceuse that had been secretly or openly espoused but was now lost." The streets were the scene of much rejoicing and celebration parties were held in many homes. Children beat drums in childigh parades, and toasts were drunk to the Union by their elders. But eive deys later the generel rejoicing was turned into deep sorrow when the word came that Iincoln was dead. All business was suspended, stores and offices were closed, and "drape in mourning" was hung in all the public offices. The sympathy of the city was touched to the extent thet a large public meeting was held to mourn for the President. Governor Bramlette presided, and with bared heads the greater part of Louisville listened as James Guthrie added his word of praise. As if the meeting were not enough, a procession three miles long silently threeded its wey through the streets, mourning for the savior of the Union.

1. Coulter, op. cit., p. 257 .

2. Collins, Kentucky, I, 158. 
But Appomattox did not at once bring peace and prosperity to the City of Louisville. Evil days were yet to come in still greater numbers. To the unemployment problem that had been vexing the city fathers for four long years was to be added the social and economic problem of the freed negro. When the state made no motion to do away with slavery many negroes fled from the rural districts and sought out Louisville as a haven of refuge. Louisville was military headquarters for the Union forces; the army had no petience with slavery; hence, Loulaville meant freedom to the slave who went there. The Louisville Journal reported thet the city was becoming blacker - and blacker as time went on; and although the army issued free passes to all comers so that they might flee the state, many slaves remained to make Louisville their home.

During the war the greater number of Louisville's citizens had been united ggeinst the Confederacy. Domestic peece and relative properity was visible throughout the life of the city. But now the question of slavery--an old question in a new 3. Coulter, op. cit., p. $25 \%$. 4. Louigvilie Journa 1, Dec. 17, 1864. 5. Ibid., $\mathrm{Feb}, 3,1865$. 
disguise--divided the people of the clty, estranged members of the same family, and created deady hatred between life-long friends and neighbors. The lincoln Republicans (Radicals) supported the amendment that would free the sleves; the Conservatives would have none of it; freeling the slaves would mean negro suffarage, negro equality, and the "prying fingers of the Federal government thrust into state affairs forevermore." The city became a hotbod of politics that even the Thirteenth Amendment could not, and did not, pacify for generatione to come.

But the negro problem was not the only problem that faced the city at the end of the war. The era of rallroad and turnpike bullding thet had been halted by the war was continued with renewed emphasis and Louisville was faced with a number of new competitors for the trade with the South. Many of the larger towns of the state were jealous of Loulsvilie's strangle-hold on Southern trade and a bitter hostility grew up throughout central Kentucky toward Louisvilie and her co-conspirator, the Louisville and Nashville Railroad. Cincinnati and central Kentucky joined

6. Cincinnati Gazette, Feb. 15, 17, 1865.

7. Ibld. Cited in Coulter, p. 260 . 
their forces to drive a rallroed directly southward, but due to a remarkable conspiracy of fate and circumstances the road was not completed unt1l 1880 , by which time Louisville had reaped the greater share of the harvest of "Reconstruction."

But after the problem of the slave had been partially solved the transition from the excitement of the war to the pursuits of peace was rapid and marked with great business activity. River trade was resumed and Louisville took up her position as a distributive point for the South. After 1866 there was a tremendous increase in the manufacturing industries. In 1870 the United States census showed, as compared with 1860, an increase of almost one hundred percent in the number of manufacturing estabI1shments and in the number of operatives employed, and of more than one hundred per cent. in the cepital invested, in the amount of the annual wages pald, as well as in the velue of annual product.

One unqualified esser tion that can be made about I1fe in Louigville during the period covered by this history is that no other epoch compares with

8. For an excellent discussion of the rivelry between Louigville and Cincinnati following the war, see Coulter, Chap. XIII, pp. 257-86.

9. Johnston, $1,104$. 10. Ib1d., 1, 277 . 
with it $m$ respects ${ }^{t_{0}}$ the growth of material wealth of the c1ty. Although there were many instances where the destructions of war left in their trail blighted hopes and ruined lives, the city on the whole profited by the war. The population of the city increased by more than thirty per cent. and the price of real estate doubled. Fortunes were made by the commercial classes, and wages for the laboring classes almost doubled.

But Louisville could never entirely get away from all the memories of the war; nor did she so desire. Even though she might sponsor a "Peace Reunion" in 1872, where "one hundred thousand patriots shake hands across the bloody chasm, ${ }^{11}$ there was no real appeal for reconciliation. As the metropolis of Kentucky she was "more Southern in habits of thought and sympathies, then, perhaps, eny former part of the Confederacy itself." But time and the prospect of still greater wealth builds a bridge across any chasm, and for the thirty years following the war Loulsville applied hergelf to the making of money.

11. Goorgetown Weekly Times, Sept. 18, 1872, cited In Coulter, p. 439 . Courier Journal, sept. 11, 1872. See also Collins, Kentucky, I, 211.

12. Coulter, op. c1t., p. 439 . 
BIBIIOGRAPHY 


\title{
B IBLIOGRAPHY
}

\author{
DOCUNATITS
}

Aots of the General Assembly of the Commonwealth of Kentucky, 1859-60.

Abraham Iincoln, Oomplete Works of, Edited by John G. IClolay and John Hay. VI. NoW York: Francis D. Tandy Co., 1905.

Journal of the Common Council of the City of Loular1l10, 1860--1865.

Rebellion Records; A Diary of Amerloan Erents, Documents, iarratives, Iliustrative Incidents, Poetry, -to. Edited by Frank Moore. I--IX. Iew York: G.P. Putnam, 1861 ff.

Stratton, O.H. and John M. Vaughn, A Collection of and Munle1pal Laws. Louisville: C. Settle, 1851.

War of the Rebelilion. The; A Compilation of the OPficial Records of the Union and Confederate Armies. 129 Volumes. Washington: Government Printing office, 1900.

NEWSPAPERS

Cinoinnat1 Commeroial, 1860--1865. Fdited by Murat Holetead. A Union paper partioulariy interested in the affairs of Kentucky and Louiavilie.

Cincinnat1 Gazette, 1860--1865. Edited by E.B. Manstiold and Richard Smith. As far as polioy and purpose were concerned, the Gazette was much the same as the Commercial, mentioned above.

- Louisville Courier, 1860-1861. Edited by Walter $N$. Haldeman. This paper came out boldly for secossion, and in September (1861) was suppressed by Federal authority. 
Louisvilie Journal, 1860-1865. Edited by George D. Prentice. This paper stood without a peer in influenoe and leadership in Kentucky and had a fame and reputation that was national.

\section{PAMPHLETS AND PERIODICALS}

Annuel Report of the Loulaville Water Company, 1861-2. Annal Report of the Louigville and Frankfort Rallroad Company, 1863.

Anmual Report of G.W. Morr18, President of the Board of Loulsrille School Trustees, 1862-3.

Annual Report of the President and Directors of the Iouisvilie and Nashrille Railroad Company, October, 1860 to June 30, 1861: Hanna \& Co., 1861; July 1, 1865 to June 3, 1866. Louisville: John P. Morton and Co., 1866.

Campbell's Iouisville Business Directory, 1864.

Cotterill, R.S., "The Louisville and Nashville Railroad Company, 1860-1865," American Hiatoricel Review, XXIX, No. 4, July, 1924.

Coulter, E. Merton, "Commercial Intercourse with the Confederacy in the Mississippi Velley," Mississippt Valloy H1storical Leview, III, No. 3, 1919.

Coulter, E. Merton, Effects of Secession Upon the Commerce of the Mlissisgippi valley," Mississippi Valley Historical Review, V, Ho. 4, 1916.

Edwara's Loulsville Directory, 1864-5; 1865-6.

Harper's Monthly hagazine, XXI. No. CIXXIII. August, 1865.

- Loularille Iibrery Collection. Collected Hritings Relating to the History of Louisville. 2 Vol. Loulsrille, 1935.

Mallallieu, W.C., "Origing of the University of Loulavilie," Filion Club History Quarterly, XII. No. 1,1937 . 
Merchant's Magazine and Commerolel Revier (Hunt's), Few York: W.B. Dana, 1860-1870.

Niles Register, VIII, XXXII, XXXV, XXXVIII, XIIII.

Putman's Monthly Magazine, VIII, No. XIIII, september, 1863.

Tanner's Louisville Directory and Business Advertiser, Loulsville, Maxwell \& Co., 1861.

\section{MAYUSCR IPTS}

Dietz, Mary Marthe, A History of the Theatre in Lou18ville, (M.A. Thesis, University of Loulsvilio) 1921.

He1tz, Flora, Comprehensive survey of Cultural Movements in Louisvillo in the 19th. Century, (M.A. Thes18, University of Loulsvillo 1937.

Loom1s, George, Notes and Reminisoences of the Volunteer Fire Department in Louigville, (FIIson CIub Arohive 1919.

Munday, Jesse, The Rellroads of Kentucky, 1860-65, (M.A. Thesis, Untversity of Loulaville) 1925.

Rodman, S.A. Reminiscences of, (MS. in Filson Club Archives) $192 \%$.

Smith, D.T., Reminiscenoes of the Civil War in Kentucky, (Filson Club Archives) 1903.

Sumners, W.T., Reminiscences of 1858 to 1878 in Louisvilie, (FIIson Club Arohives) 1919.

\section{SXCONDARY WORKS}

Brittan, Belle, A Tour of Newport, New York: Derby and Jackson, 1858 .

Collins, Lewis and Richard H. Collins, Collins

Historloal Sketohes of Kentucky. History OI, Rerlsed Edition. 2 Vol. Corington: Collins \& CO., 1882. 
Clark, D.Y., History of Kentucky, New York: PrenticeHe11, Ino., 193\%.

Connelley, W.C. and E. Merton Coulter, History of Kentucky, 2 Vol. Chicago: Americen Historloal Society, 1922。

Coulter, E. Merton, The Civil War and Readjustment in Kentucky, Chapei HIII: UnIversity of Iorth Carolina Press, 1926.

Dabney, Virginius, Liberalism in the old South, Chapel Hill: University of North Carolina Press, 1932 .

-Deering, Richard, Louigville, Her Commercial, Manufecturing, and Soc1al Advantager, Loulsvilie: Hanna and Co., 1859 .

Gohdes, C.I., The Poriodicals of Transcendentalism, Durham: Duke University Pres8, 1931.

History of the Ohio Falls Cities and Their Counties, With Blographioal sketches, 2 Vol. Cleveland: L.A. WIIIIams and Co., 1881 .

Johnston, J. Stoddard, Memorlal History of Louigville, 2 Vol. New York: American Blograpgioal Co., 1896.

Kinkhead, E.S., History of Kentuoky, New York: American Book Co., 1896.

Massie, J.W., Amer10a, John Snow, 1864.

Perrin, W.H. \& J.H. Battle, \& G.C. Kniffin, History of Louigville, 1888.

Polk, Dr. J.J., Autoblography of, Louirville: John Morton, 1867.

Ruak, R.I., The Literature of the Midale Western Frontier, 2 Vol. Columbia University Press, 1926.

Shaler, N.S., Kentucky, A Ploneer Commonwealth, Boston: Houghton, Miffín and Co., 1888.

Speed, Thomas, The Union Ceuse in Kentuoky, 1860-5, New York: G.P. Putman's Sons, 1907. 
Sweet, W.W., The Methodiat Episcopal Church and the Civ11 War, Louisville: Me thodlet Book Concern, I912.

The South in the Bullaing of a Nation, 8 Vol. Rlchmond: Southern Publication Soclety, 1909.

Townsend, John Wilson, Kentucky in American Letters, 1784--1912, 2 Vol. New York: Torch Pro88, 1913. 